\title{
Dual Emissive Ir(III) Complexes for Photodynamic Therapy and Bioimaging
}

\author{
Marta Redrado ${ }^{1}$, Andrea Benedi ${ }^{2}$ D, Isabel Marzo ${ }^{2} \mathbb{D}$, M. Concepción Gimeno ${ }^{1, *(D)}$ \\ and Vanesa Fernández-Moreira $1, *$ (i) \\ 1 Departamento de Química Inorgánica, Instituto de Síntesis Química y Catálisis Homogénea (ISQCH), \\ CSIC-Universidad de Zaragoza, 50009 Zaragoza, Spain; marta@unizar.es \\ 2 Departamento de Bioquímica y Biología Celular, Universidad de Zaragoza-CSIC, 50009 Zaragoza, Spain; \\ andreabenedi94@gmail.com (A.B.); imarzo@unizar.es (I.M.) \\ * Correspondence: gimeno@unizar.es (M.C.G.); vanesa@unizar.es (V.F.-M.); Tel.: +34-976-762-291 (M.C.G.); \\ +34-796-761-183 (V.F.-M.)
}

Citation: Redrado, M.; Benedi, A.;

Marzo, I.; Gimeno, M.C.;

Fernández-Moreira, V. Dual Emissive Ir(III) Complexes for Photodynamic Therapy and Bioimaging. Pharmaceutics 2021, 13, 1382. https:// doi.org/10.3390/pharmaceutics13091382

Academic Editor:

Maria Nowakowska

Received: 28 July 2021

Accepted: 29 August 2021

Published: 1 September 2021

Publisher's Note: MDPI stays neutral with regard to jurisdictional claims in published maps and institutional affiliations.

Copyright: (c) 2021 by the authors. Licensee MDPI, Basel, Switzerland. This article is an open access article distributed under the terms and conditions of the Creative Commons Attribution (CC BY) license (https:/ / creativecommons.org/licenses/by/ $4.0 /)$.
Abstract: Photodynamic therapy (PDT) is a cancer treatment still bearing enormous prospects of improvement. Within the toolbox of PDT, developing photosensitizers (PSs) that can specifically reach tumor cells and promote the generation of high concentration of reactive oxygen species (ROS) is a constant research goal. Mitochondria is known as a highly appealing target for PSs, thus being able to assess the biodistribution of the PSs prior to its light activation would be crucial for therapeutic maximization. Bifunctional $\operatorname{Ir}(\mathrm{III})$ complexes of the type $\left[\operatorname{Ir}\left(\mathrm{C}^{\wedge} \mathrm{N}\right)_{2}\left(\mathrm{~N}^{\wedge} \mathrm{N}-\mathrm{R}\right)\right]^{+}$, where $\mathrm{N}^{\wedge} \mathrm{C}$ is either phenylpyridine (ppy) or benzoquinoline (bzq), $\mathrm{N}^{\wedge} \mathrm{N}$ is $2,2^{\prime}$-dipyridylamine (dpa) and $R$ either anthracene ( 1 and 3 ) or acridine (2 and 4), have been developed as novel trackable PSs agents. Activation of the tracking or therapeutic function could be achieved specifically by irradiating the complex with a different light wavelength (405 nm vs. $470 \mathrm{~nm}$ respectively). Only complex $4\left(\left[\operatorname{Ir}(\mathrm{bzq})_{2}(\mathrm{dpa}-\mathrm{acr})\right]^{+}\right)$clearly showed dual emissive pattern, acridine based emission between 407-450 nm vs. Ir(III) based emission between 521 and $547 \mathrm{~nm}$. The sensitivity of A549 lung cancer cells to 4 evidenced the importance of involving the metal center within the activation process of the PS, reaching values of photosensitivity over 110 times higher than in dark conditions. Moreover, complex 4 promoted apoptotic cell death and possibly the paraptotic pathway, as well as higher ROS generation under irradiation than in dark conditions. Complexes 2-4 accumulated in the mitochondria but species 2 and 4 also localizes in other subcellular organelles.

Keywords: photodynamic therapy; iridium; fluorescence microscopy; mitochondria; cytotoxicity; optical properties; dual emiter

\section{Introduction}

Photodynamic therapy is an underdeveloped cancer treatment that is attracting much attention recently due to the great prospect for destroying tumors and tumor vasculature as well as stimulating the immune response [1-3]. This treatment modality is based in three key pillars, a photosensitizer (PS), light and oxygen, rendering toxicity limited to the regions where the three components are together. Traditionally, organic scaffolds such porphyrins, chlorin or bacteriochlorin derivatives are used as PSs relying on their efficiency to generate highly toxic reactive oxygen species (ROS) upon irradiation at a specific light wavelength in presence of molecular oxygen [4]. Ideally, an optimum PSs should compile some common features like: (a) have strong absorption in the red/near infrared (NIR) region of the electromagnetic spectrum to allow the treatment of inner and bigger tumors; (b) have high quantum yield of the triple excited state formation and relatively long lifetime to generate ROS species effectively; (c) have minimum dark toxicity as well as a fast clearance from the body in order to avoid additional side effect to the patients and, last but not less important, (d) have a short and highly yielding 
synthetic route affording single and well characterized PSs [5]. Lately, transition metal complexes based on $\mathrm{Ru}$, Os and Ir, among others, have been investigated as alternative to commercially available organic PSs to fulfill these premises [6]. In general, transition $\mathrm{d}^{6}$ metal complexes have tunable photophysical properties: high kinetic stability and low photobleaching character. The presence of the metal helps spin-orbit coupling, leading to ultrafast and efficient population of triplet excited states, and promoting high yields of singlet oxygen generation [7]. The successful incorporation in clinical trials of a $\mathrm{Ru}(\mathrm{II})$ complex, specifically TLD1433, developed by Prof. McFarland and coworkers for the treatment of bladder cancer with PDT, has encouraged to further investigate in this field, Figure 1 [8]. In addition to $\mathrm{Ru}(\mathrm{II})$ species, also $\mathrm{Ir}(\mathrm{III})$ complexes have demonstrated their great capacity as PSs [9]. A throughout design leads to Ir(III) complexes exhibiting high quantum yields for the triplet excited state and thus enabling the efficient generation of ROS species [10]. Alternatively, to this therapy function, $\operatorname{Ir}(\mathrm{III})$ complexes have also demonstrated to be suitable luminescent probes to target different organelles within the cells. Thus, many of them have been described to selectively localize preferentially in mitochondria [11], nuclei [12] or lysosomes [13] among other inner compartments, or even pass through one organelle to another [14] by simple modification of their ligand scaffolds.

In addition to that, many reports suggest that a PS targeting mitochondria is prone to enhance their potency of photodynamic therapy due to the distinct biological features of mitochondria [15]. In fact, there is a current trend in drug design for the development of mitochondrial targeted drugs due to their indispensable role in the regulation of cell functions [16]. Mitochondria are decisive regulators of apoptosis, and they produce most of the cell's energy. They contain a high concentration of oxygen, which is one of the three main pillars of PDT. It was demonstrated that even low levels of singlet oxygen produced in the mitochondria are more toxic than large amounts produced in other parts of the cells like cell membrane or nucleus [17]. Actually, many of the commercially available PSs, such as Photofrin [18], Verteporfin [19] or Redaporfin [20,21], partially target mitochondria, where they display the therapeutic potential (Figure 1). In this sense being able to assess the biodistribution of the probe to ensure its successful delivery to mitochondria prior activating the therapeutic function will be key for maximizing its therapeutic potential.
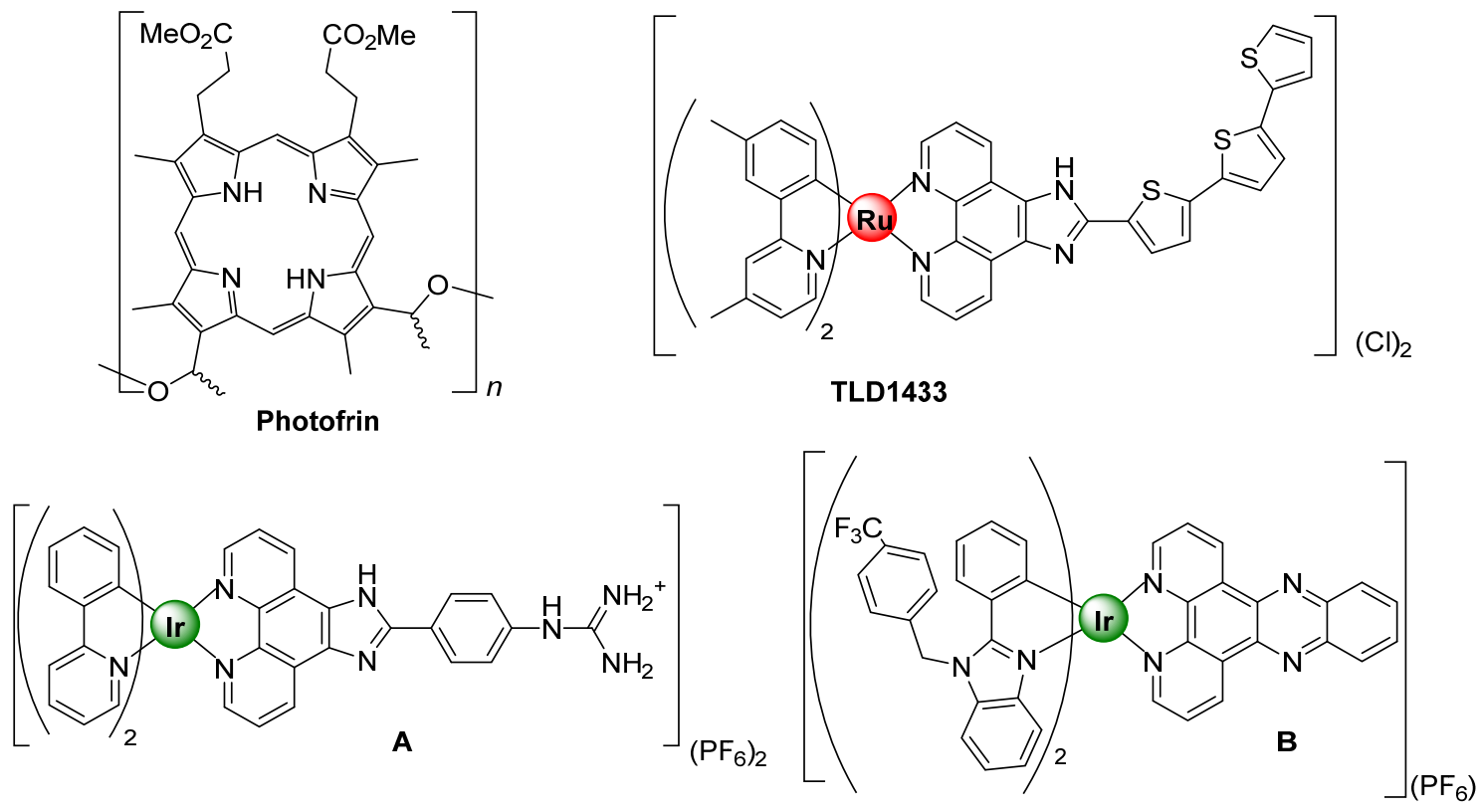

Figure 1. Chemical structures of Photofrin, TLD1433, and complexes (A,B) adapted from $[8,18,22,23]$.

With all this knowledge in mind, we propose to develop a bifunctional mitochondrial selective Ir(III) complex that can act as both, PSs and cell imaging probe, by activating each function with a different irradiation wavelength. The design approach relies on the 
incorporation of a luminescent tag to an Ir(III) PSs with well differentiated optical properties from that of the metallic fragment, i.e., a spectral photophysical separation should be taken into consideration (Figure 2). For doing so, an organic chromophore would be coupled to any ligand within the $\operatorname{Ir}(\mathrm{III})$ coordination sphere. Typically, $\operatorname{Ir}(\mathrm{III})$ complexes for PSs rely on the structure of cationic species derived from $\left[\operatorname{Ir}\left(\mathrm{C}^{\wedge} \mathrm{N}\right)_{2}\left(\mathrm{~N}^{\wedge} \mathrm{N}\right)\right]^{+}$, where $\mathrm{C}^{\wedge} \mathrm{N}$ represents an orthometallated and $\mathrm{N}^{\wedge} \mathrm{N}$ a bisimine ligand. Therefore, taking the synthetic versatility that offers the bisimine $2,2^{\prime}$-dipyridylamine (dpa), where a chromophore like anthracene could be easily coupled to the amine as previously described by Zhua [24], we envisioned that it would be feasible the incorporation of analogous chromophores (acridine) using a similar methodology. In this way, an organic chromophore could be incorporated to the Ir(III) metallic scaffold offering the possibility of tracking the complex within the cells, using a different irradiation light wavelength from that of therapy activation. This work is aimed at delivering the first synthetic steps towards a rationale design of bifunctional metalloprobes within the area o PTD and cell imaging agents.

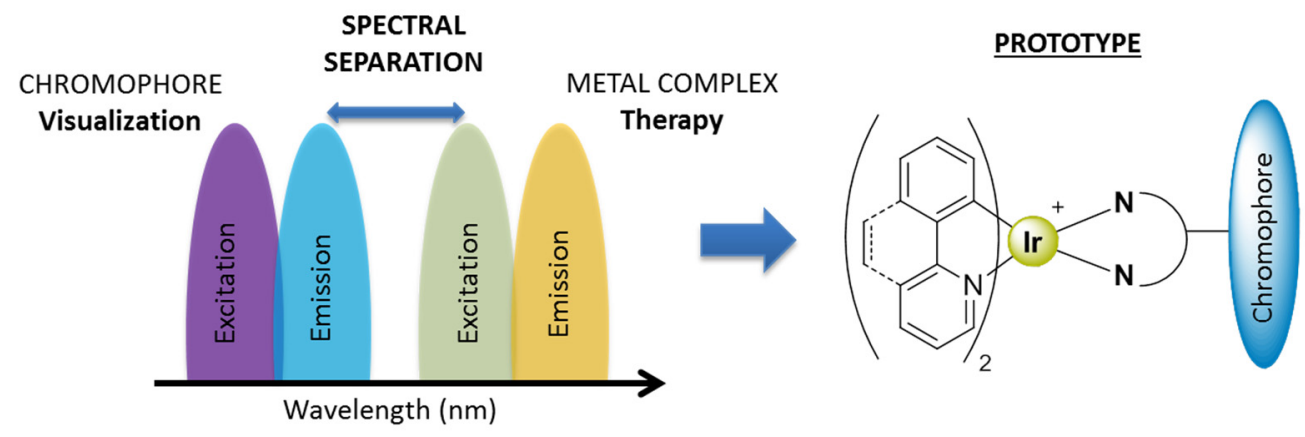

Figure 2. Depiction of the devised dual emissive Ir(III) PSs.

\section{Materials and Methods}

\subsection{Instrumentation}

${ }^{1} \mathrm{H}$ and ${ }^{13} \mathrm{C}-\left\{{ }^{1} \mathrm{H}\right\} \mathrm{NMR}$, including $2 \mathrm{D}$ experiments, were recorded at room temperature (rt) on a BRUKER AVANCE 300 spectrometer (Bruker, Billerica, MA, USA) $\left({ }^{1} \mathrm{H}-300 \mathrm{MHz}\right.$, $\left.{ }^{13} \mathrm{C}-75 \mathrm{MHz}\right)$ with chemical shifts $(\delta, \mathrm{ppm})$ reported relative to the solvent peaks of the deuterated solvent [25]. Mass spectra were recorded on a BRUKER ESQUIRE 3000 PLUS (Bruker, Boston, MA, USA), with the electrospray (ESI) technique. Steady-state photoluminescence analysis was performed in a Jobin-Yvon-Horiba fluorolog FL-3-11 spectrometer (Jobin Ybon Inc., Edison, NJ, USA). UV - Vis data were collected on an Evolution 600 spectrophotometer (Thermo Electron Scientifc Instrument LLC., Madison, WI, USA) using $1 \mathrm{~cm}$ quartz cells. Quantum yields were measured in a Hamamatsu Photonics Quantaurus-QY C11347-11 (Hamamatsu Photonics K.K., Hamamatsu City, Japan) via an absolute method, using an excitation scanning mode. The specific procedure entailed the measurement of each sample in aerated DMSO solution at room temperature (rt) after recording the reference sample (neat DSMO) in the same conditions. This procedure was repeated three times to confirm reproducibility and the quantum yield value given was this obtained at $440 \mathrm{~nm}$ excitation.

\subsection{Cell Culture}

Human lung carcinoma A549 cell line (from ATCC, Manassas, VA, USA) was cultured in high glucose Dubecco's Modified Eagle's Medium (DMEM) supplemented with 5\% fetal bovine serum (FBS) as well as L-glutamine and penicillin/streptomycin at $37^{\circ} \mathrm{C}$ in a humidified atmosphere of $95 \%$ air and $5 \% \mathrm{CO}_{2}$.

\subsection{Cell Viability Assays}

Cell metabolic activity was analyzed by an MTT-reduction assay to assess the A549 cell sensitivity to the complexes. Thus, $10^{5}$ cells(A549)/ $\mathrm{mL}$ were seeded in flat-bottom $96-$-well plates $(100 \mu \mathrm{L} /$ well) in complete medium and allowed to attach for $24 \mathrm{~h}$. A stock solution 
of the complexes was prepared in DMSO 0.1 M. Subsequent dilutions of the different stock solutions from the complexes using DMEM were prepared. $100 \mu \mathrm{L} /$ well were added to the cells, in concentrations ranging from 0.2 to $50 \mu \mathrm{M}$. each concentration was performed by quadruplicate. After $5 \mathrm{~h}$ of incubation with the complexes, duplicates of each concentration were irradiated with an LED lamp upon 405 and $470 \mathrm{~nm}$ with a light dose of 6.5 and $15.1 \mathrm{~J} / \mathrm{m}^{2}$, respectively, for $10 \mathrm{~min}$. Before irradiation, culture medium was replaced with fresh medium in order to avoid interference with non-internalized complexes. Cells were cultured for a further $19 \mathrm{~h} .10 \mu \mathrm{L}$ of MTT ( $5 \mathrm{mg} \mathrm{ml}^{-1}$ in PBS) were added to each well and then further $2 \mathrm{~h}$ incubation was allowed at $37^{\circ} \mathrm{C}$. Finally, after removing the culture medium, DMSO $(100 \mu \mathrm{L} /$ well $)$ was added to dissolve the formazan crystals. Multiskan EX 96-well multiscanner autoreader (Thermo Fisher Scientific, Waltham, MA, USA) was used to determine the optical density at $550 \mathrm{~nm}$ and $\mathrm{IC}_{50}$ was calculated. Each experiment was repeated at least three independent analyses.

\subsection{Cytotoxicity Assays}

Necrotic and apoptotic cell death was determined by measuring cell membrane permeabilization and phosphatidylserine exposure on cell surface in A549 cells, respectively. $10^{5}$ cells / well were seeded in flat-bottom, 12 -well plates $(1 \mathrm{~mL} /$ well $)$ in complete medium and left $12 \mathrm{~h}$ to attach to the plates. Cells were incubated with complex 4 for $5 \mathrm{~h}$, at concentrations of the $\mathrm{IC}_{50}, \frac{1}{2} \mathrm{IC}_{50}$ and $\frac{1}{4} \mathrm{IC}_{50}$ in quadruplicate before changing culture medium and irradiating at $470 \mathrm{~nm}$ of half of the experimental points. After $19 \mathrm{~h}$, cells were trypsinized and thereafter resuspended in $50 \mu \mathrm{L}$ of a mixture of DY634-conjugated Annexin $\mathrm{V}$, Annexin-binding buffer (ABB; $140 \mathrm{mM} \mathrm{NaCl}, 2.5 \mathrm{mM} \mathrm{CaCl}_{2}, 10 \mathrm{mM}$ HEPES/NaOH $\mathrm{pH}$ 7.4) and 7-amino-actinomycin D (7-AAD). After incubation for further $15 \mathrm{~min}$ at $\mathrm{rt}$ in dark, cells were diluted to $300 \mu \mathrm{L}$ with ABB. A total of 10,000 cells were acquired on a FACSCalibur ${ }^{\mathrm{TM}}$ flow cytometer (BD Biosciences, San Jose, CA, USA) and cell death analysis was performed using Flowjo 7.6.1 (Becton Dickinson (BD), Franklin Lakes, NJ, USA), CellQuest Pro (BD Biosciences) and GraphPad Prism 8 (GraphPad Software, San Diego, CA, USA) softwares.

\subsection{ROS Production Measurement}

A549 cells $\left(4 \times 10^{5}\right.$ cells $/$ well $)$ were seeded in flat-bottom, 6-well plates $(3 \mathrm{~mL} /$ well $)$ in complete medium and allowed attaching for $24 \mathrm{~h}$. thereafter a DMSO solution of complex 4 added to cells up to concentration of $\mathrm{IC}_{50}, \frac{1}{2} \mathrm{IC}_{50}$ and $\frac{1}{4} \mathrm{IC}_{50}$ in duplicate. Cells were incubated with the complex for $5 \mathrm{~h}$ and subsequently half of the experimental points were irradiated at $470 \mathrm{~nm}$ after replacing culture medium. Upon $19 \mathrm{~h}$, cells were trypsinized, resuspended in $100 \mu \mathrm{L}$ of a mixture of PBS and $2 \mu \mathrm{M}$ of the dihydroethidium (DHE) probe, incubated at $37^{\circ} \mathrm{C}$ in the dark for $15 \mathrm{~min}$ and diluted to $300 \mu \mathrm{L}$ with PBS. Lastly, a total of 10,000 events were acquired on a FACSCalibur ${ }^{\mathrm{TM}}$ flow cytometer and data were analyzed using the aforementioned softwares

\subsection{Cell Cycle Analysis}

$4 \times 105$. A549 cells/well were seeded in complete medium in flat-bottom, 6-well plates ( $3 \mathrm{~mL} /$ well), left overnight to be attached to the bottom and incubated with complex 4 at the concentration of $\frac{1}{4} \mathrm{IC}_{50}$ for $5 \mathrm{~h}$ in quadruplicate. Thereupon, cell culture was changed, and half of the experimental points were irradiated at $470 \mathrm{~nm}$. After $19 \mathrm{~h}$ in culture, cells were trypsinized, washed twice with PBS, fixed with cold $70 \%$ ethanol $(v / v)$ by vortexing and stored at $-20^{\circ} \mathrm{C}$ for at least $24 \mathrm{~h}$. After that, cells were wash with cold PBS and stained with $500 \mu \mathrm{L}$ of a solution of propidium iodide (PI) and RNase (Immunostep, Salamanca, Spain) for $20 \mathrm{~min}$ at rt in the dark. Finally, a total of 10,000 cells were acquired on a FACSCalibur ${ }^{\mathrm{TM}}$ flow cytometer and data were analyzed using the aforementioned softwares. 


\subsection{Fluorescence Confocal Microscopy}

A549 cells $\left(8 \times 10^{3}\right.$ cells $/$ well $)$ were seeded in $\mu$-slide 8 well (ibiTreat) $(300 \mu \mathrm{L} /$ well $)$ in complete medium and left $24 \mathrm{~h}$ to get attached to the bottom of the slide. After removing $200 \mu \mathrm{L}$ of culture medium from each well, $100 \mu \mathrm{L}$ of a solution of the corresponding complexes were added reaching a final concentration of $2 \mu \mathrm{M}$. The complexes were incubated with the cells for $24 \mathrm{~h}$, and thereafter, the internal standard MitoTracker Red (MTR) was added to a final concentration of $15 \mathrm{nM}$. MTR was incubated with the cells for further $15 \mathrm{~min}$ at rt. Finally, the medium of each well was replaced with fresh medium phenol red free. Images were collected in a ZEISS LSM 880 confocal microscope in a sequential mode with a 40 oil immersion lens. Specifically, it was used a line average of 4 , a format of $1024 \times 1024$ pixels and a excitation wavelength of either $458 \mathrm{~nm}$ or $588 \mathrm{~nm}$ with a confocal pinhole of 1 Airy unit. Images were analyzed ZEISS ZEN lite (blue edition) a free software.

\subsection{Distribution Coefficient $\left(\log P_{7.4}\right)$}

The n-octanol-water coefficient of complexes 1-4 and L1 and L2 were determined using a shake-flask method [26]. A mixture of buffered-saline distilled water $(100 \mathrm{~mL}$, phosphate buffer $\left.\left[\mathrm{PO}_{4}{ }^{3-}\right]=10 \mathrm{mM},[\mathrm{NaCl}]=0.15 \mathrm{M}, \mathrm{pH} 7.4\right)$ and n-octanol $(100 \mathrm{~mL})$ was shaken for $72 \mathrm{~h}$ to allow saturation of both phases. Approximately $0.5 \mathrm{mg}$ of the complexes or ligands werw dissolved in $5 \mathrm{~mL}$ of the aqueous phase and $5 \mathrm{~mL}$ of the organic phase were added, mixing for $10 \mathrm{~min}$. The resulting emulsion was centrifuged to separate the phases. The concentration of the compounds in each phase was determined using UV absorbance spectroscopy at $298 \mathrm{~K} . \log \mathrm{P}_{7.4}$ was defined as $\log \{[$ compound(organic phase)]/[compound(aqueous phase)]\}.

\subsection{Starting Materials}

The starting material $\left[\operatorname{Ir}(\mathrm{ppy})_{2}(\mu-\mathrm{Cl})\right]_{2}$ and $\left[\operatorname{Ir}(\mathrm{bzq})_{2}(\mu-\mathrm{Cl})\right]_{2}[27]$, were prepared according to published procedures. Each experimental data agrees with that already reported somewhere else. Other reagents and solvents were commercially available from SigmaAldrich, and used without further purification. Manipulations were performed under argon atmosphere.

\subsection{General Synthetic Procedures}

\subsubsection{Synthetic Procedure of Ligands L1 and L2}

An equimolar mixture of 2,2'-dipyridylamine $(100 \mathrm{mg}$; $0.584 \mathrm{mmol})$ and 9-bromoanthracene (L1) (151.7 mg; $0.584 \mathrm{mmol})$ or 9-chloroacridine (L2) (128.52 mg; $0.584 \mathrm{mmol}$ ) was solved in $5 \mathrm{ml}$ of toluene, when it became soluble, potassium tert-butoxide $(77 \mathrm{mg}$; $0.65 \mathrm{mmol}$ ) was added to the solution. The reaction mixture was refluxed overnight. The volume of toluene was reduced under vacuum, affording a pale solid, which was filtered and dried affording L1 (162.2 mg; 80\% yield) or L2 (196.76 mg; 96\% yield). L1: ${ }^{1} \mathrm{H}$ NMR $\left(300 \mathrm{MHz}\right.$, Acetone- $\left.\mathrm{d}_{6}\right) \delta 8.69(\mathrm{~s}, 1 \mathrm{H}), 8.50(\mathrm{~d}, J=8.9 \mathrm{~Hz}, 2 \mathrm{H}), 8.22(\mathrm{~d}, J=3.9 \mathrm{~Hz}, 2 \mathrm{H}), 8.16$ $(\mathrm{d}, J=8.4 \mathrm{~Hz}, 2 \mathrm{H}), 7.82(\mathrm{~d}, J=8.4 \mathrm{~Hz}, 2 \mathrm{H}), 7.74-7.56(\mathrm{~m}, 6 \mathrm{H}), 6.89-6.80(\mathrm{~m}, 2 \mathrm{H}) \mathrm{ppm} .{ }^{13} \mathrm{C}$ NMR $\left(75 \mathrm{MHz}\right.$, Acetone- $\left.\mathrm{d}_{6}\right) \delta 149.6,148.40,140.8,138.2,137.5,129.8,128.6,128.5,127.9$, $126.9,126.8,116.8,112.6,103.0$ ppm. L2: ${ }^{1} \mathrm{H}$ NMR $\left(300 \mathrm{MHz}\right.$, Acetone- $\left.\mathrm{d}_{6}\right) \delta 8.48(\mathrm{~d}, J=8.8$ $\mathrm{Hz}, 2 \mathrm{H}), 8.25-8.20(\mathrm{~m}, 4 \mathrm{H}), 7.96-7.90(\mathrm{~m}, 2 \mathrm{H}), 7.84-7.75(\mathrm{~m}, 4 \mathrm{H}), 7.68-7.61(\mathrm{~m}, 2 \mathrm{H}), 6.85$ $(\mathrm{ddd}, J=7.2,5.0,1.0 \mathrm{~Hz}, 2 \mathrm{H}) \mathrm{ppm} .{ }^{13} \mathrm{C}$ NMR $\left(75 \mathrm{MHz}\right.$, Acetone- $\left.\mathrm{d}_{6}\right) \delta 148.4,138.2,131.6$, $130.9,128.4,125.1,116.8,112.6,110.4,110.4$ ppm. HRMS (ESI): $m / z$ calcd. for $\mathrm{C}_{23} \mathrm{H}_{16} \mathrm{~N}_{4}$ 348.1375; found: $349.1453(\mathrm{~L} 2+\mathrm{H})$.

\subsubsection{Synthetic Procedure of Complexes 1-2}

$\left[\operatorname{Ir}(\mathrm{ppy})_{2}(\mu-\mathrm{Cl})\right]_{2}(50 \mathrm{mg}, 0.046 \mathrm{mmol})$ was solved in $5 \mathrm{~mL}$ of $\mathrm{MeOH}$, then $\mathrm{L} 1$ or L2 was added to the solution in an equimolar proportion (L1, $32.38 \mathrm{mg}$ or L2, $32.47 \mathrm{mg}$ ). The reaction mixture was refluxed for $15 \mathrm{~h}$ in argon atmosphere. The resultant suspension was cooled, and the yellow solid was isolated by filtration affording $40.4 \mathrm{mg}$ of 1 ( $92 \%$ yield) or $41.19 \mathrm{mg}$ of 2 (94\% yield) respectively. Complex $1:{ }^{1} \mathrm{H} \mathrm{NMR}\left(300 \mathrm{MHz}, \mathrm{CD}_{2} \mathrm{Cl}_{2}\right) \delta 8.43(\mathrm{dd}$, 
$J=9.1,0.9 \mathrm{~Hz}, 3 \mathrm{H}), 8.13(\mathrm{ddd}, J=5.8,1.6,0.8 \mathrm{~Hz}, 2 \mathrm{H}), 7.98-7.94(\mathrm{~m}, 2 \mathrm{H}), 7.85(\mathrm{ddd}, J=8.4$, $1.5,0.8 \mathrm{~Hz}, 2 \mathrm{H}), 7.73(\mathrm{ddd}, J=8.2,7.3,1.5 \mathrm{~Hz}, 2 \mathrm{H}), 7.60-7.39$ (m, 12H), $7.04(\mathrm{ddd}, J=7.4$, $5.8,1.5 \mathrm{~Hz}, 2 \mathrm{H}), 6.89(\mathrm{ddd}, J=7.8,7.3,1.3 \mathrm{~Hz}, 2 \mathrm{H}), 6.74(\mathrm{td}, J=7.4,1.4 \mathrm{~Hz}, 2 \mathrm{H}), 6.42(\mathrm{t}$, $J=6.5 \mathrm{~Hz}, 2 \mathrm{H}), 6.08(\mathrm{ddd}, J=7.5,1.3,0.5 \mathrm{~Hz}, 2 \mathrm{H}) \mathrm{ppm} .{ }^{13} \mathrm{C} \mathrm{NMR}\left(75 \mathrm{MHz}, \mathrm{CD}_{2} \mathrm{Cl}_{2}\right) \delta 168.3$, 168.3, 163.0, 152.9, 150.0, 150.0, 149.8, 149.8, 144.5, 144.5, 138.8, 138.8, 138.5, 138.5, 132.3, $132.3,130.8,130.8,129.2,129.2,127.9,127.9,127.8,127.8,127.77,127.7,126.3,126.3,125.2$, $125.2,123.4,123.4,122.7,122.7,120.2,120.2,117.9$ ppm. Complex $2:{ }^{1} \mathrm{H}$ NMR $(300 \mathrm{MHz}$, $\left.\mathrm{CD}_{2} \mathrm{Cl}_{2}\right) \delta 8.46-8.30(\mathrm{~m}, 6 \mathrm{H}), 8.21(\mathrm{~d}, J=8.2 \mathrm{~Hz}, 2 \mathrm{H}), 8.00(\mathrm{t}, J=7.7 \mathrm{~Hz}, 2 \mathrm{H}), 7.84-7.52(\mathrm{~m}$, $10 \mathrm{H}), 7.33(\mathrm{dd}, J=7.4,5.8 \mathrm{~Hz}, 2 \mathrm{H}), 7.25(\mathrm{dd}, J=8.2,6.8 \mathrm{~Hz}, 2 \mathrm{H}), 6.94(\mathrm{t}, J=7.5 \mathrm{~Hz}, 2 \mathrm{H}), 6.81$ $(\mathrm{t}, J=7.4 \mathrm{~Hz}, 2 \mathrm{H}), 6.69(\mathrm{t}, J=6.5 \mathrm{~Hz}, 2 \mathrm{H}), 6.20(\mathrm{~d}, J=7.6 \mathrm{~Hz}, 2 \mathrm{H}) \mathrm{ppm} .{ }^{13} \mathrm{C} \mathrm{NMR}(75 \mathrm{MHz}$, $\left.\mathrm{CD}_{2} \mathrm{Cl}_{2}\right) \delta 167.7,152.1,152.0,150.4,149.4,149.3,149.2,143.9,138.5,138.0,133.4,131.7,130.3$, $126.5,124.7,122.9,122.2,121.5,119.7,118.4,117.3,116.9$ ppm. HRMS (ESI): $m / z$ calcd. for $\mathrm{C}_{45} \mathrm{H}_{32} \mathrm{IrN}_{6}$ 849.2318; found: $872.5459(2+\mathrm{Na})$.

\subsubsection{Synthetic Procedure of Complexes 3-4}

$\left[\operatorname{Ir}(\mathrm{bzq})_{2}(\mu-\mathrm{Cl})\right]_{2}(50 \mathrm{mg}, 0.043 \mathrm{mmol})$ was solved in $5 \mathrm{~mL}$ of $\mathrm{MeOH}$, then L1 or L2 was added to the solution in an equimolar proportion (L1, $29.72 \mathrm{mg}$ or L2, $29.94 \mathrm{mg})$. The reaction mixture was refluxed for $15 \mathrm{~h}$ in argon atmosphere. The resultant suspension was cooled, and the yellow solid was isolated by filtration affording $24.6 \mathrm{mg}$ of 3 (61\% yield) or $40.08 \mathrm{mg}$ of 4 (99\% yield) respectively. Complex 3: ${ }^{1} \mathrm{H} \mathrm{NMR}\left(300 \mathrm{MHz}, \mathrm{CD}_{2} \mathrm{Cl}_{2}\right) \delta 8.59-8.47$ $(\mathrm{m}, 5 \mathrm{H}), 8.38-8.31(\mathrm{~m}, 2 \mathrm{H}), 8.25(\mathrm{~d}, J=8.6 \mathrm{~Hz}, 2 \mathrm{H}), 8.04(\mathrm{dd}, J=8.4,1.3 \mathrm{~Hz}, 2 \mathrm{H}), 7.83(\mathrm{~d}$, $J=8.8 \mathrm{~Hz}, 2 \mathrm{H}), 7.72(\mathrm{~d}, J=8.8 \mathrm{~Hz}, 2 \mathrm{H}), 7.67-7.48(\mathrm{~m}, 8 \mathrm{H}), 7.41(\mathrm{dd}, J=8.0,0.9 \mathrm{~Hz}, 2 \mathrm{H}), 7.03$ $(\mathrm{dd}, J=7.9,7.2 \mathrm{~Hz}, 2 \mathrm{H}), 6.45-6.39(\mathrm{~m}, 2 \mathrm{H}), 6.08(\mathrm{dd}, J=7.2,0.9 \mathrm{~Hz}, 2 \mathrm{H}) \mathrm{ppm} .{ }^{13} \mathrm{C}$ NMR $\left(75 \mathrm{MHz}, \mathrm{CD}_{2} \mathrm{Cl}_{2}\right) \delta 171.9,149.7,148.7,146.9,145.9,140.7,138.5,137.0,129.7,129.4,129.0$, 128.6, 127.4, 127.3, 127.2, 125.7, 123.8, 121.9, 120.2, 118.3, 117.0, 111.8, 105.7 ppm. Complex 4: ${ }^{1} \mathrm{H}$ NMR (300 MHz, $\left.\mathrm{CD}_{2} \mathrm{Cl}_{2}\right) \delta 8.54(\mathrm{~d}, J=5.3 \mathrm{~Hz}, 2 \mathrm{H}), 8.47(\mathrm{t}, J=9.5 \mathrm{~Hz}, 4 \mathrm{H}), 8.33(\mathrm{~d}$, $J=8.1 \mathrm{~Hz}, 2 \mathrm{H}), 8.25(\mathrm{~d}, J=1.2 \mathrm{~Hz}, 2 \mathrm{H}), 7.86-7.82(\mathrm{~m}, 4 \mathrm{H}), 7.71-7.68(\mathrm{~m}, 4 \mathrm{H}), 7.60-7.49(\mathrm{~m}$, $6 \mathrm{H}), 7.39(\mathrm{~d}, J=7.8 \mathrm{~Hz}, 2 \mathrm{H}), 7.04(\mathrm{t}, J=7.5 \mathrm{~Hz}, 2 \mathrm{H}), 6.46-6.38(\mathrm{~m}, 2 \mathrm{H}), 6.08(\mathrm{~d}, J=7.1 \mathrm{~Hz}$, 2H) ppm. ${ }^{13} \mathrm{C}$ NMR $\left(75 \mathrm{MHz}, \mathrm{CD}_{2} \mathrm{Cl}_{2}\right) \delta 152.3,149.7,149.0,148.7,138.6,137.1,134.3,132.7$, 130.6, 129.7, 129.4, 129.0, 127.4, 123.8, 121.8, 120.2, 118.3, 116.9 ppm. HRMS (ESI): $\mathrm{m} / z$ calcd. for $\mathrm{C}_{49} \mathrm{H}_{32} \mathrm{IrN}_{6}$ 897.2318; found: $906.8221(4+\mathrm{Li}-\mathrm{H})$.

\section{Results and Discussion}

\subsection{Preparation and Characterization of Complexes 1-4 and Ligands L1 and L2}

The synthetic approach for developing bifunctional mitochondrial selective Ir(III) complexes that can act as both, PSs and cell imaging probes entails the combination of a bioactive Ir(III) yellow / green emissive fragment with a blue emissive organic chromophore (acridine or anthracene), both of them connected by 2,2'-dipyridylamine (dpa). As typically the emission of $\operatorname{Ir}(\mathrm{III})$ fragments of the type $\left[\operatorname{Ir}\left(\mathrm{C}^{\wedge} \mathrm{N}\right)_{2}\left(\mathrm{~N}^{\wedge} \mathrm{N}\right)\right]^{+}$is highly conditioned by the nature of cyclometallated ligand, ppy and bzq will be used to fine tune the metal based optical properties.

Starting from the dpa and following a slightly modified procedure described by our research group [28,29], ligands L1 and L2 were synthesized, see Scheme 1. Specifically, by treating dpa in presence of ${ }^{\mathrm{t}} \mathrm{BuOK}$ in toluene, it was plausible to deprotonate the amine group and coordinate the correspondent chromophore, anthracene or acridine, starting from their halogen precursors. After that, the different $\operatorname{Ir}(\mathrm{III})$ complexes were obtained by refluxing together stoichiometric amounts of $\mathbf{L} 1$ or $\mathbf{L} 2$ and $\left[\operatorname{Ir}(\mathrm{ppy})_{2}(\mu-\mathrm{Cl})\right]_{2}$ or $\left[\operatorname{Ir}(\mathrm{bzq})_{2}(\mu-\right.$ $\mathrm{Cl})]_{2}$ in methanol. Complexes 1-4, as well as ligands $\mathbf{L 1}$ and $\mathbf{L 2}$, were obtained in high yield as detailed in the experimental section. Their structures were fully characterized using ${ }^{1} \mathrm{H}$ and ${ }^{13} \mathrm{C}$ NMR spectroscopy and mass spectrometry, corroborating the accomplishment on their synthesis (Figures S1-S12). In all cases, ${ }^{1} \mathrm{H}$ NMR spectra were well defined and showed the typical patterns for the dipyridylamine derivatives coordinated to a cyclometallated $\operatorname{Ir}(\mathrm{III})$ core. Specifically, the pyridine protons of the $\mathrm{N}^{\wedge} \mathrm{N}$ ligands shift to lower field with respect to the free ligand. Additionally, which could be appreciated in the 
shift of the aromatic $\mathrm{CH}$ proton in para position to the nitrogen of the pyridyl ring of $\mathbf{L 2}$, see Scheme 1 and Figure S3. The doublet of doublet peak at $7.65 \mathrm{ppm}$ observed in the free ligand $\mathbf{L} 2$, shifted to 7.24 and $7.01 \mathrm{ppm}$ in complexes $\mathbf{2}$ and 4, respectively. Simultaneously, a set of eight resonances (each integrating as $2 \mathrm{H}$ ) is observed for the two orthometallated ligands, due to the $\mathrm{C}_{2}$ symmetric nature of these complexes. Furthermore, another set of four resonances is observed for the two pyridyl rings present in the $\mathrm{N}^{\wedge} \mathrm{N}$ ligands [30]. Similar shifts and ${ }^{1} \mathrm{H}$ NMR patterns were found for complexes $\mathbf{1}$ and $\mathbf{3}$. Additionally, the stability of the complexes was assessed by ${ }^{1} \mathrm{H}$ NMR spectroscopy in DCM solution. All of them were stable for at least $48 \mathrm{~h}$.

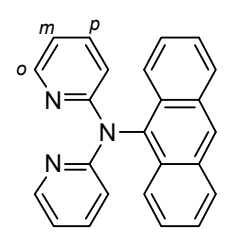

L1

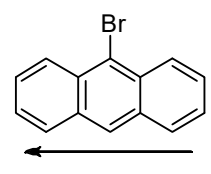

i)

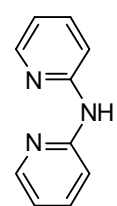

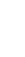<smiles>CCCCCCCCC</smiles>

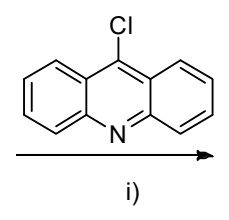<smiles>c1ccc(N(c2ccccn2)c2c3ccccc3nc3ccccc23)nc1</smiles>

L2

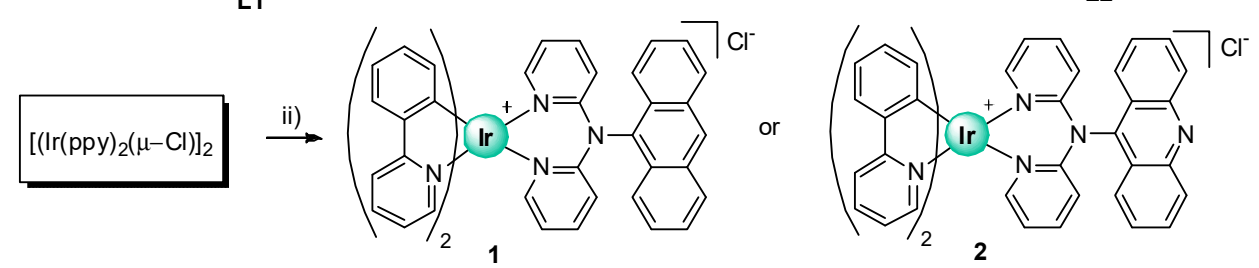

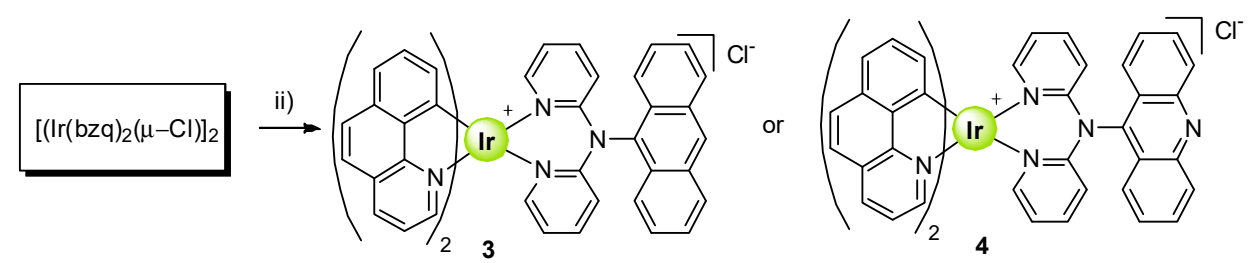

Scheme 1. Synthetic pathway for the synthesis of $\mathbf{L} 1$ and $\mathbf{L} 2$ and complexes 1-4. Reaction conditions as follow: (i) ${ }^{\mathrm{t}} \mathrm{BuOK}$, toluene, reflux, $12 \mathrm{~h}$; (ii) $\mathrm{MeOH}$, reflux, $15 \mathrm{~h}$ under Ar.

\subsection{Optical Properties of Complexes 1-4}

Photophysical properties of complexes 1-4 and L1 and L2 were measured in DMSO solution at rt. DMSO was specifically chosen for these studies to gain information of the photophysical behavior of the complexes in a polar media. Moreover, DMSO is also used to prepare the stock solutions of the complexes for the biological assays; therefore, it is a good approximation to know the photophysics of the complexes in biological media. Data collected from UV-vis absorption and emission spectroscopy are depicted in Table 1.

Table 1. Photophysical data of L1, L2 and 1-4 measured in aerated DMSO solution.

\begin{tabular}{|c|c|c|c|c|}
\hline & UV-vis ${ }^{\text {a }}\left(\times 10^{3} \varepsilon / \mathrm{dm}^{3} \mathrm{~mol}^{-1} \mathrm{~cm}^{-1}\right) / \mathrm{nm}$ & $\lambda_{\text {em }}\left[\lambda_{\text {exc }}\right](\mathrm{nm})^{b}$ & $\tau(\mathrm{ns})^{b}$ & $\Phi(\%)^{c}$ \\
\hline L1 & 260 (47.5), $318(8.7), 355(3.4), 373(5.2), 394$ (4.5) & $405,422,448[375]$ & - & - \\
\hline L2 & $260(47.5), 270(30.7), 317(16.2), 350(7.5), 362(9.8), 388(5.4)$ & $409,431,557[400]$ & - & - \\
\hline 1 & 260 (94.4), $320(14.5), 354(10.0), 375(10.7), 395(8.9), 424$ (3.9) & $486,515 s, 551[437]$ & 186 & 8.3 \\
\hline 2 & $260(87.5), 273(68.1), 310(25.4), 380(20.2), 400(22.1), 427(6.5)$ & $485,514[433]$ & 210 & 8.4 \\
\hline 3 & $260(43.4), 324(9.4), 353(6.7), 374(5.5), 394(3.9), 423(1.8)$ & $521 \mathrm{~s}, 551 \mathrm{~s}[432]$ & 242 & 6.4 \\
\hline 4 & $260(39.1), 271(35.1), 308(12.9), 380(10.1), 398(11.5), 425(3.2)$ & $521 \mathrm{~s}, 547 \mathrm{~s} 407 \mathrm{~s}, 432,458[450]$ & 451 & 10 \\
\hline
\end{tabular}

${ }^{\mathrm{a}}$ in DMSO solution: $\mathbf{L 1}$ and $\mathbf{L} 2$ at $\left[2 \cdot 10^{-5} \mathrm{M}\right]$ and complexes $1-\mathbf{4}$ at $\left[10^{-5} \mathrm{M}\right] .{ }^{\mathrm{b}}$ In aerated DMSO solution. ${ }^{\mathrm{c}}$ In aerated DMSO at $\left[2.5 \cdot 10^{-5} \mathrm{M}\right]$.

Specifically, complexes 1-4 showed the typical absorption spectrum for cationic species of the type $\left.\left[\operatorname{Ir}\left(\mathrm{C}^{\wedge} \mathrm{N}\right)_{2}\left(\mathrm{~N}^{\wedge} \mathrm{N}\right)\right)\right]^{+}$, where the UV region is dominated by spin allowed ligand centered $\left({ }^{1} \mathrm{LC}, \pi \rightarrow \pi^{*}\right)$ transitions and the region between 350 and $450 \mathrm{~nm}$, by less intense 
absorption bands correspondent to ${ }^{1} \mathrm{MLCT}$ and ${ }^{1}$ LLCT transitions, Figure S19. [31] In addition, the weak long tail observed over $450 \mathrm{~nm}$ is assigned to the direct excitation of spin forbidden ${ }^{3} \mathrm{MLCT},{ }^{3} \mathrm{LLCT}$ and ${ }^{3} \mathrm{LC}$ transitions, which are taking place because of the high spin-orbit coupling of the iridium metal (Figure S19). Regarding the emissive properties, the complexes showed a strong emission band between 485 and $515 \mathrm{~nm}(\mathbf{1}$ and 2) and between 521 and $547 \mathrm{~nm}$ (3 and 4) (Figure 3).
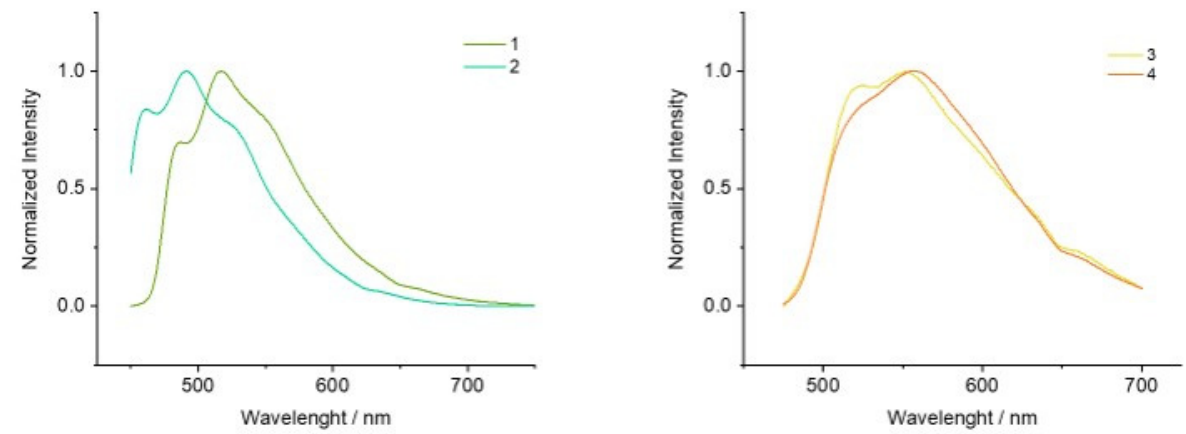

Figure 3. Emission spectra of complexes 1-4 in DMSO solution at $298 \mathrm{~K}$.

Such a small red shift observed from both families is related with the increment of the aromaticity of the cyclometallated ligand, going from a ppy in complexes $\mathbf{1}$ and $\mathbf{2}$ to a bzq in complexes 3 and 4. Generally, the highest-occupied molecular orbital (HOMO) is and admixture of $\operatorname{Ir} \mathrm{d} \pi$ orbitals $\left(\mathrm{t}_{2 \mathrm{~g}}\right)$ and the $\pi$ orbitals of the cyclometallated ligand, therefore higher aromaticity on the $\mathrm{C}^{\wedge} \mathrm{N}$ ligand leads to a destabilization of the HOMO orbitals and consequently a red shift on the emission is observed [32]. The nature of the emission is associated with an admixture of ${ }^{3} \mathrm{MLCT}$ and ${ }^{3} \mathrm{LLCT}$ transitions for complexes 1-4. Moreover, it is worth highlighting that when irradiation of complexes between 375 and $400 \mathrm{~nm}$ an additional high energetic emissive band is observed; see Figures 4 and S15-S18. The new band has a structured pattern that resembles that of $\mathbf{L} 1$ and $\mathbf{L 2}$ and, specifically, that of the anthracene and acridine chromophores (Figures S13 and S14). Such emission band has its maximum intensity when the excitation is taking place around $400 \mathrm{~nm}$, and it can be attributed to a ${ }^{1} \mathrm{LC}$ transition within the chromophore. This secondary emission has a higher contribution in the case of complexes 3 and 4 , possibly due to the fact that the emission derived from the triplet state is red shifted (c.a. $521 \mathrm{~nm}$ ) in comparison with that of complexes 1 and 2 (c.a. $486 \mathrm{~nm}$ ) and therefore, facilitating its detection. Figure 4 shows the emissive and excitation profile of complex 4 when irradiated at different excitation wavelengths, demonstrating that upon selection of the excitation wavelength, the main emission displayed by the species can be shifted, from a chromophore based to an Irbased emission. Similar analysis is depicted in the supporting information in Figures S15-S17 for complexes 1-3. Regarding the lifetimes of the excited state, all complexes presented a lifetime value between $186-456 \mathrm{~ns}$ for the iridium-based emission, similar to that of $\left[\operatorname{Ir}(\mathrm{ppy})_{2}(\mathrm{bpy})\right] \mathrm{PF}_{6}[33]$ and indicating the phosphorescence nature of the process. Additionally, quantum yields were registered in aerated DMSO, revealing values between 6.5 and $10 \%$. 

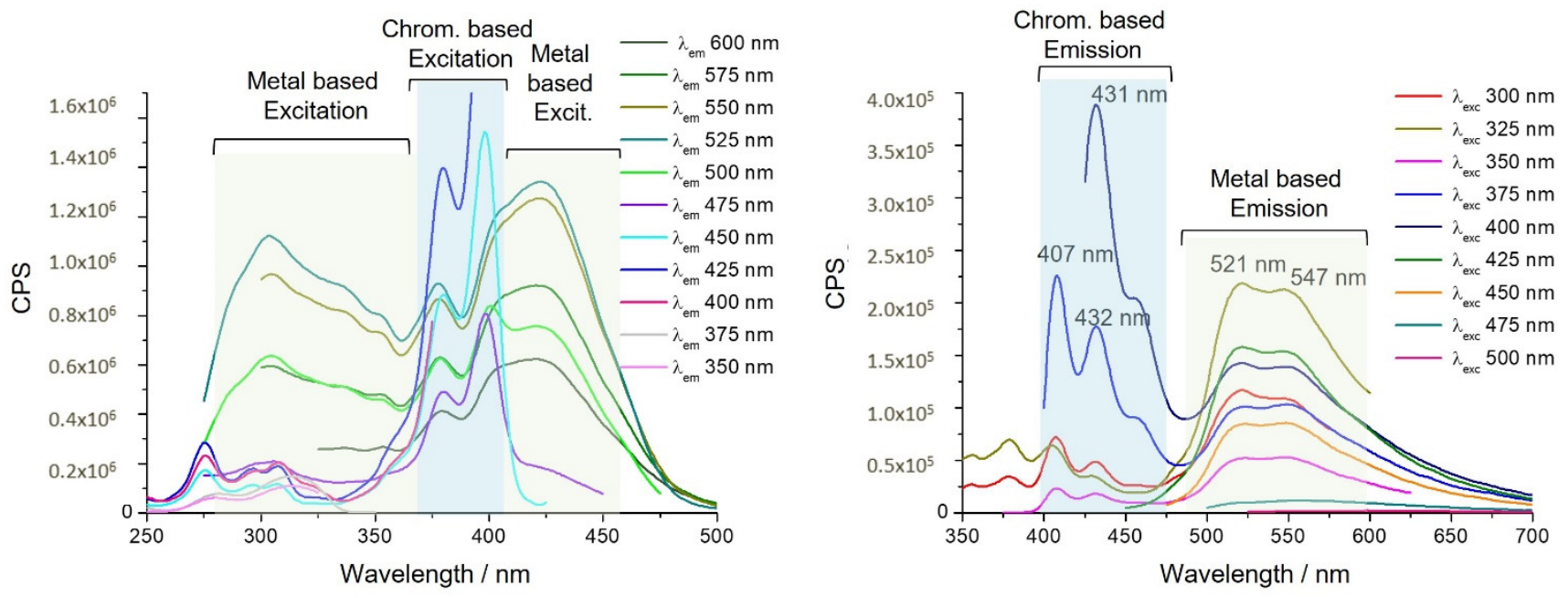

Figure 4. Excitation spectra (left) of complex 4 for the different emission profiles and the correspondent emission spectra (right) upon excitation at different wavelengths.

\subsection{Antiproliferative Activity of Complexes 1-4}

The sensitivity of A549 lung carcinoma cells to 1-4 and L1 and L2 was examined by MTT-reduction assays after $24 \mathrm{~h}$ of treatment. Data gathered in Table 2 reveals that complexes 1-3 displayed a moderate antiproliferative activity, with $\mathrm{IC}_{50}$ values between $13.6 \mu \mathrm{M}$ and $19.6 \mu \mathrm{M}$ followed from afar by compound 4 , which yielded a $\mathrm{IC}_{50}$ value of $43.38 \mu \mathrm{M}$. Conversely, high $\mathrm{IC}_{50}$ values obtained for both ligands involves that they did not perturbed cell viability at the studied concentration range. These results therefore suggest that the bioactivity falls to the metallic fragment. Alternatively, additional photosensitivity studies were performed using an irradiation wavelength of 405 and $470 \mathrm{~nm}$ to elucidate whether these complexes could be used as PSs as well as the optimum excitation wavelength. Thus, A549 cells were incubated with complexes for $5 \mathrm{~h}$, for $10 \mathrm{~min}$ at either $405 \mathrm{~nm}$ or $470 \mathrm{~nm}$ and kept in culture for a further $19 \mathrm{~h}$. Despite reducing the $\mathrm{IC}_{50}$ values from 7 to 14 times when irradiation at $405 \mathrm{~nm}$ was performed, it is actually the irradiation at $470 \mathrm{~nm}$ when the greatest antiproliferative effect is detected for all complexes. The $\mathrm{IC}_{50}$ values for all the complexes dropped to the nanomolar range. Among all them it is striking the behavior of complex 4 as cells showed little sensitivity to this complex under no irradiation conditions $(43.38 \pm 0.14 \mu \mathrm{M})$ but they were extremely sensitive when irradiated at $470 \mathrm{~nm}$, reducing its $\mathrm{IC}_{50}$ value more than 110 times and matching its antiproliferative capacity to compounds 2 and 3. Keeping in mind that good PSs should only reveal anticancer properties under irradiation conditions, compound 4 is proposed to be the best PS agent from the series complexes 1-4. On the other hand, the marked difference in bioactivity offered between the two irradiation wavelengths is probably due to the diverse nature of the excited state when irradiating at 405 or at $470 \mathrm{~nm}$. Irradiation of the complexes at $405 \mathrm{~nm}$ is mainly affecting the organic chromophore. On the contrary, irradiation at $470 \mathrm{~nm}$ excites exclusively the iridium fragment, which by means of the heavy atom effect evolves effectively to a triplet excited state, with longer excited state lifetimes and affording better PS source for photodynamic therapy. 
Table 2. $\mathrm{IC}_{50}$ values of complexes 1-4 and L1-L2 incubated for $24 \mathrm{~h}$ in A549 cells.

\begin{tabular}{|c|c|c|c|c|c|}
\hline Complexes & $\mathrm{IC}_{50 \text { (DARK) }}$ & $\mathrm{IC}_{50(\lambda \operatorname{exc} 405 \mathrm{~nm})} 1$ & PI & $\mathrm{IC}_{50(\lambda \operatorname{exc} 470 \mathrm{~nm})}{ }^{1}$ & PI \\
\hline L1 & $>50$ & - & & - & \\
\hline L2 & $>50$ & - & & - & \\
\hline 1 & $13.6 \pm 0.08$ & $1.16 \pm 0.06$ & 11.7 & $0.18 \pm 0.05$ & 75.5 \\
\hline 2 & $19.6 \pm 0.68$ & $2.54 \pm 0.08$ & 7.7 & $0.34 \pm 0.06$ & 57.6 \\
\hline 3 & $18.9 \pm 0.12$ & $1.35 \pm 0.08$ & 14.0 & $0.40 \pm 0.08$ & 47.2 \\
\hline 4 & $43.38 \pm 0.14$ & $>5$ & & $0.39 \pm 0.09$ & 111.2 \\
\hline
\end{tabular}

${ }^{1} \mathrm{IC}_{50}$ values in $\mu \mathrm{M}$, irradiation time: $10 \mathrm{~min}$ at 405 or $470 \mathrm{~nm}$ after $5 \mathrm{~h}$ incubation. (PI: Phototoxic index).

\subsection{Cell Morphology}

Alterations in cell morphology and behavior as a consequence of the exposition to ligands and complexes were analyzed using an inverted microscope (Figure 5). As expected, healthy cells displayed an epithelial-like morphology, and they grew exponentially (data not shown). A similar appearance was observed when treating cells with $\mathbf{L 1}$ and $\mathbf{L} 2$ as several dividing cells were discerned and apoptotic or necrotic cells were not detected. Oppositely, complexes 1-4 were able to modify cell aspect. All of them triggered cytoplasmic vesicle formation, which was more remarkable for compounds $\mathbf{3}$ and $\mathbf{4}$, containing the bzq orthometallated ligand. Moreover, even though cell division still took place in the presence of all of them, it became patently clear that they have cytotoxic properties, being more evident for complexes $\mathbf{1}$ and $\mathbf{2}$.

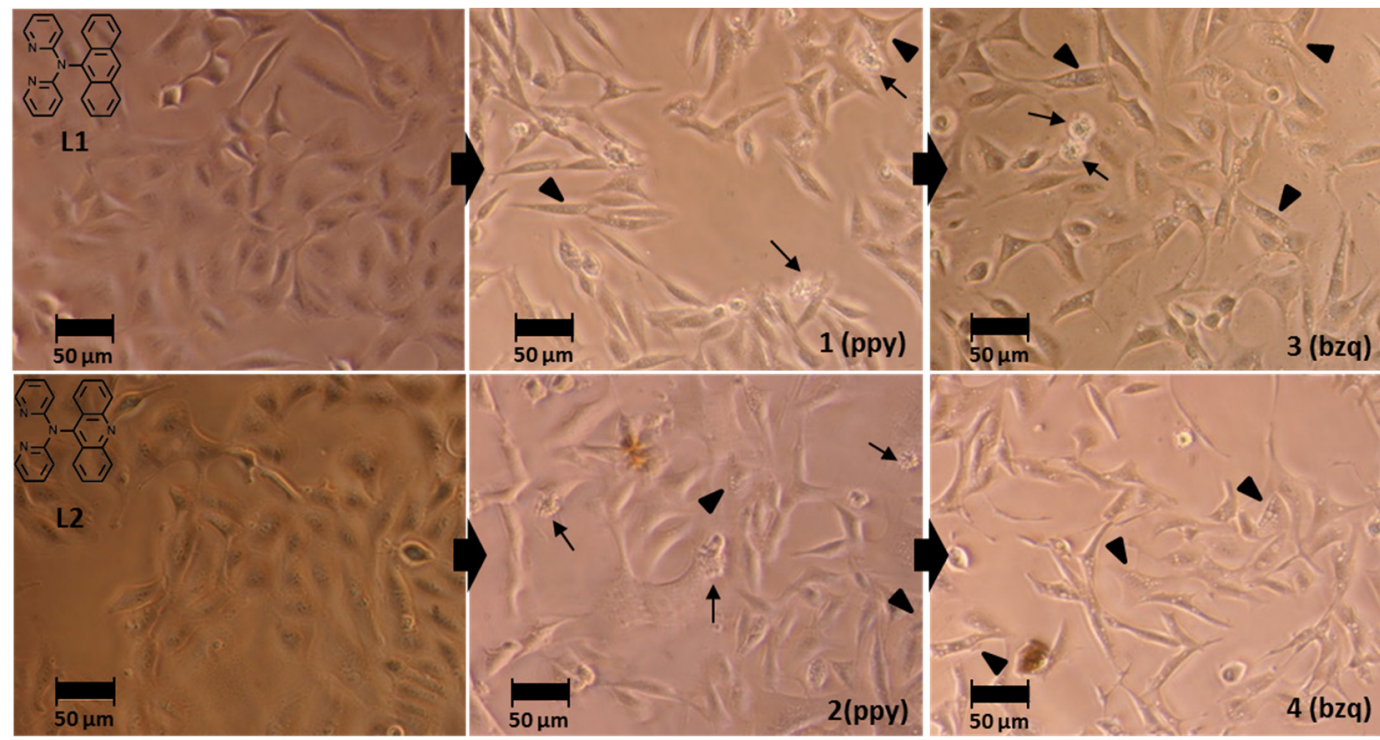

Figure 5. Phase contrast microscopy images of A549 cells treated with L1, L2 and 1-4 at concentrations between 10 and $20 \mu \mathrm{M}$ for $20 \mathrm{~h}$. Black arrows point to apoptotic cells. Little black triangles show examples of cells containing cytoplasmic vesicles.

\subsection{Cytotoxic Activity, Cell Cycle Arrest of Complex 4 and Partition Coeficient Octanol Water for 1-4 and L1-L2}

Previously to cytotoxicity assays, cells were visualized under an inverted microscope in order to observe morphological changes. As expected, control cells were growing exponentially but treatments provoked large cytoplasmic vacuolization and apoptotic and necrotic morphologies (data not shown).

Cytotoxic potential of complex 4 was analyzed by flow cytometry using the simultaneous double staining of Annexin V-DY634 and 7-AAD in both, dark and under irradiation conditions ( $\lambda_{\text {exc }}: 470 \mathrm{~nm}$ ). Dead cells that preserve cell membrane integrity exhibit phosphatidylserine on cell surface. This exposition is a typical feature of 'early apoptosis' and it can be detected by flow cytometry thanks to protein Annexin V conjugated with different 
fluorophores, which selectively binds to this phospholipid in the presence of calcium [34]. However, cells with compromised cell membrane (necrotic cells) allow DNA labeling with fluorescent intercalating agents such as 7-AAD. Furthermore, cells can be double stained by undergoing "late apoptosis" as they initiate the apoptotic process and end up suffering secondary necrosis upon loss of membrane integrity. As shown in Figure 6, complex 4 displayed a concentration-dependent cytotoxic activity in both conditions. Although in both cases the death of the cells was induced, the way in which they died differs. When cells were not irradiated, they underwent early and late apoptosis, with the late state predominating at low dose and reaching a similar distribution between both states at high concentrations. However, irradiated cells mostly reached the late apoptotic state although apoptotic cells at the early state were also detected. Therefore, these results suggest that complex 4 triggers the apoptotic pathway in A549 cells under dark and irradiation conditions. In addition, since massive cytoplasmic vacuolization is a hallmark of paraptosis [35], we assume that this type of programmed cell death coexists with apoptosis though more exhaustive studies are necessary to confirm this hypothesis.
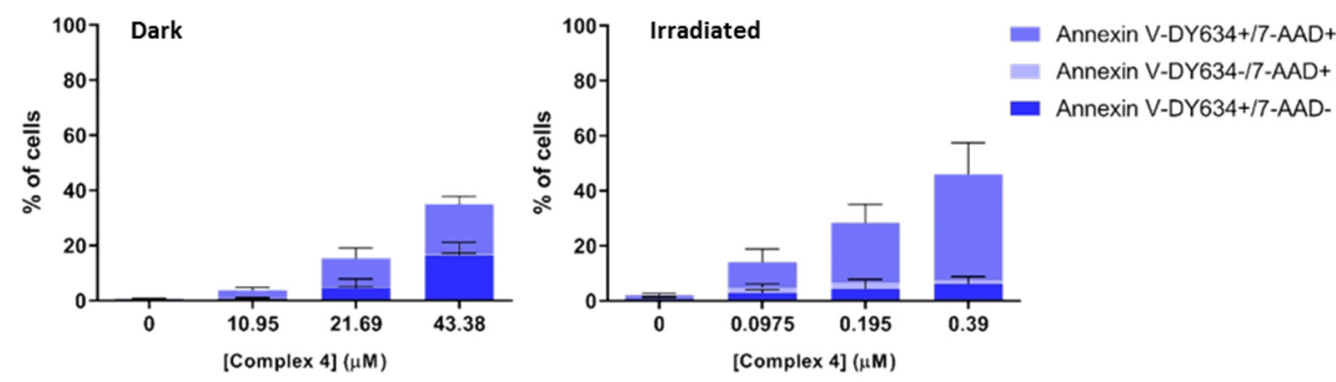

Figure 6. Cytotoxicity assays of complex 4, when it was incubated in A549 cell line for $24 \mathrm{~h}$, in a range of concentration between its $\mathrm{IC}_{50}$ and $\frac{1}{4} \mathrm{IC}_{50}$ values. In dark (left); Under irradiation at $470 \mathrm{~nm}$ (right).

To delve into the mechanism of action of the complex, we decided to evaluate its ability to modify cell cycle. The cell cycle is a vital process for cells as it implies their replication and thus, the survival of the cells. Biologically wise is an ordered series of events involving cell growth and cell division to eventually produce two identical cells [36]. Specifically, four different phases define the cell cycle: cells grow and are metabolically active throughout G1 phase, they duplicate their DNA content during $S$ phase, prepare for cell division in the course of $\mathrm{G} 2$ phase and finally they divide resulting in two daughter cells during M phase, each of which will carry out its own cell cycle. G1, S and G2 phases in turn constitute the interphase, the stage of the cell cycle where cells spend most of the time. Cell cycle was analyzed in presence of complex 4 in dark and upon irradiation conditions. The objective of this experiment is to elucidate if the increment of antiproliferative potential upon irradiation of complex 4 at low concentrations could be related with its ability of inducing cell cycle arrest at any of its phases, which might be different from its behavior in dark conditions. Figure 7 indicates that untreated cells in dark conditions and upon irradiation at $470 \mathrm{~nm}$ for $10 \mathrm{~min}$ behave similarly. In both cases they present the typical cell cycle pattern for healthy cells, where most of them are growing exponentially at the G0/G1 phase. In addition, the cell distribution at the different phases is hardly disturbed with respect to their respective controls upon the different treatments. Consequently, the results obtained seem to indicate that complex 4 is not capable of stopping the cell cycle at any of its phases in both under dark and irradiation conditions. 

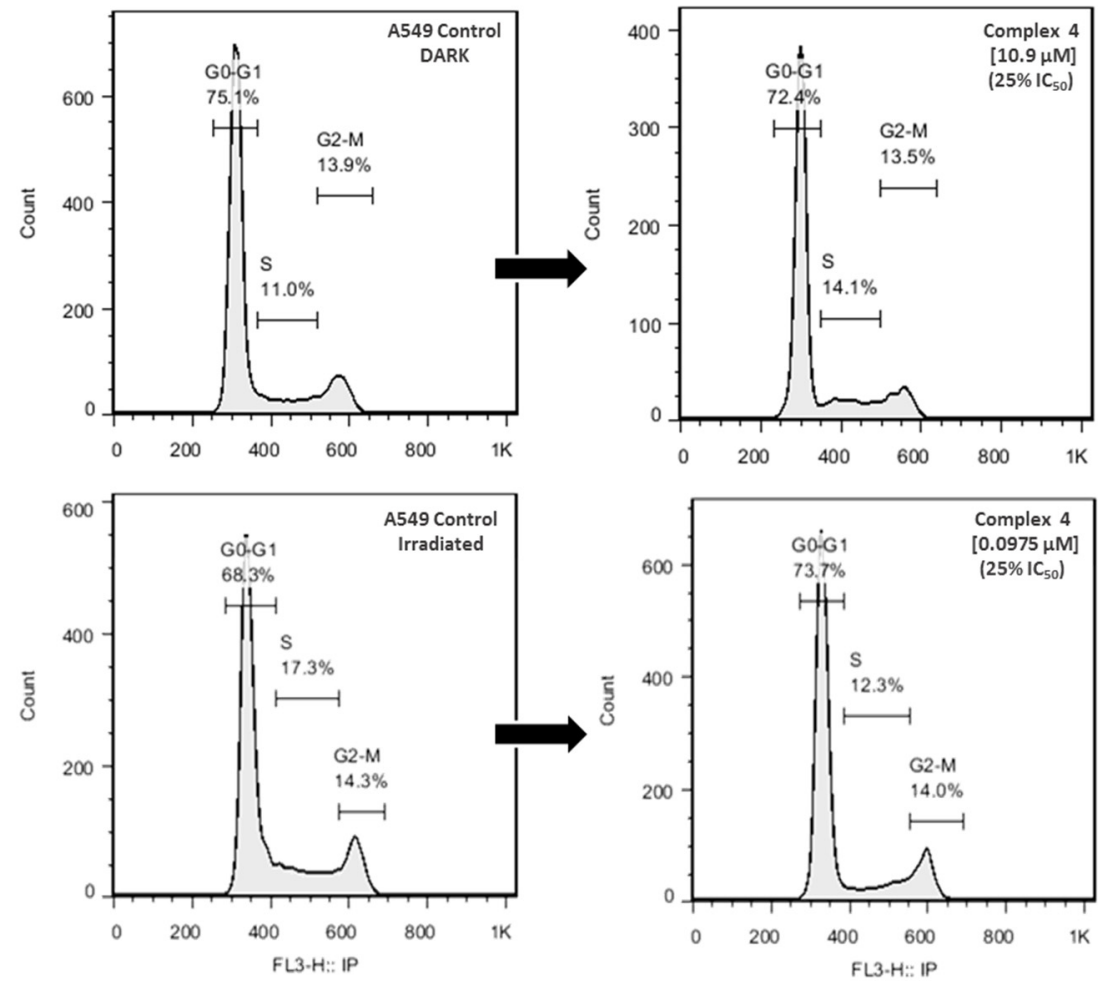

Figure 7. Cell cycle analysis after treatment with complex 4 in dark (top graphs) and under irradiation at $470 \mathrm{~nm}$ (bottom graphs). The cell distribution at each phase is indicated for each graphic.

Additionally, the ratio lipophilicity: hydrophilicity can be measured by the partition coefficient water/n-octanol, $\log \mathrm{P}$, by experimental procedures such as the shake flask method among others [37]. The value of $\log P$ indicates the distribution of the drug between an equal amount of n-octanol and buffered aqueous solution. In early drug discovery, assessing the lipophilicity of a potential drug is essential to predict to it physicochemical behavior in vivo, and it is one of the parameters use in Lipinky rule for assessing the druglikeness of a compound [38]. Table 3 displays $\log P$ for all the complexes as well as L1 and L2. Thus, $\log P$ values ranges from 0.28 in the case of complex 2, being the less lipophilic, to 1.73 for complex 3 at the other far end. These results are in concordance with intrinsic higher lipophilicity of $\mathbf{L} \mathbf{1}$ vs. $\mathbf{L} \mathbf{2}$ added to the more lipophilic nature of the orthometalated bzq in complexes $\mathbf{3}$ and $\mathbf{4}$ vs. ppy in $\mathbf{1}$ and $\mathbf{2}$.

Table 3. $\log \mathrm{P}$ values of complexes $1-4$ at $\mathrm{pH}=7.4$.

\begin{tabular}{cccccc}
\hline Ligands & $\log \mathrm{P}(\mathrm{Oct} / \mathrm{W})$ & Complexes & $\log \mathrm{P}(\mathrm{Oct} / \mathrm{W})$ & Complexes & $\log \mathrm{P}(\mathrm{Oct} / \mathrm{W})$ \\
\hline L1 & 1.20 & $\mathbf{1}$ & 0.75 & $\mathbf{3}$ & 1.73 \\
L2 & 0.59 & $\mathbf{2}$ & 0.28 & $\mathbf{4}$ & 1.24 \\
\hline
\end{tabular}

\subsection{Subcellular Localization of Complexes $\mathbf{1}-\mathbf{4}$}

Confocal microscopy assays were carried out to elucidate the biodistribution of complexes 2-4 in A549 cells, and to further assess the possibility of targeting mitochondria due to their great importance as biological targets in PDT [15,17]. Therefore, a colocalization assay was performed where complexes 2-4 were incubated with A549 cells together with a commercially available mitochondrial selective dye (MitoTracker-red, MTR). Figure 8 shows slightly different emission patterns for each complex. While complex 2 and especially 3 display a punctate emission pattern, that emitted by complex 4 is more diffuse. In any case, complex 3 fully colocalizes with the signal emitted by MTR indicating its mitochondrial localization, whereas complexes $\mathbf{2}$ and $\mathbf{4}$ do so partially. 

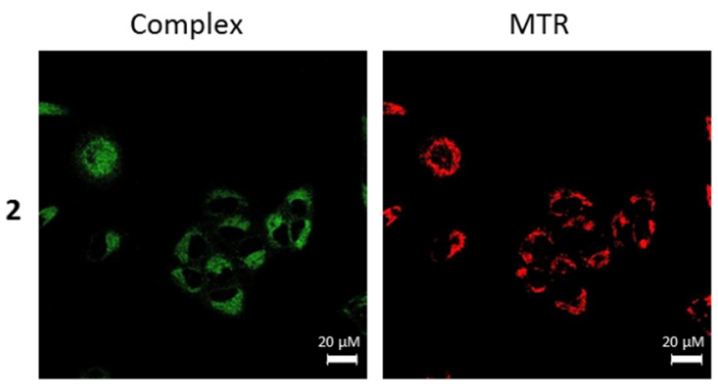

Superimposition
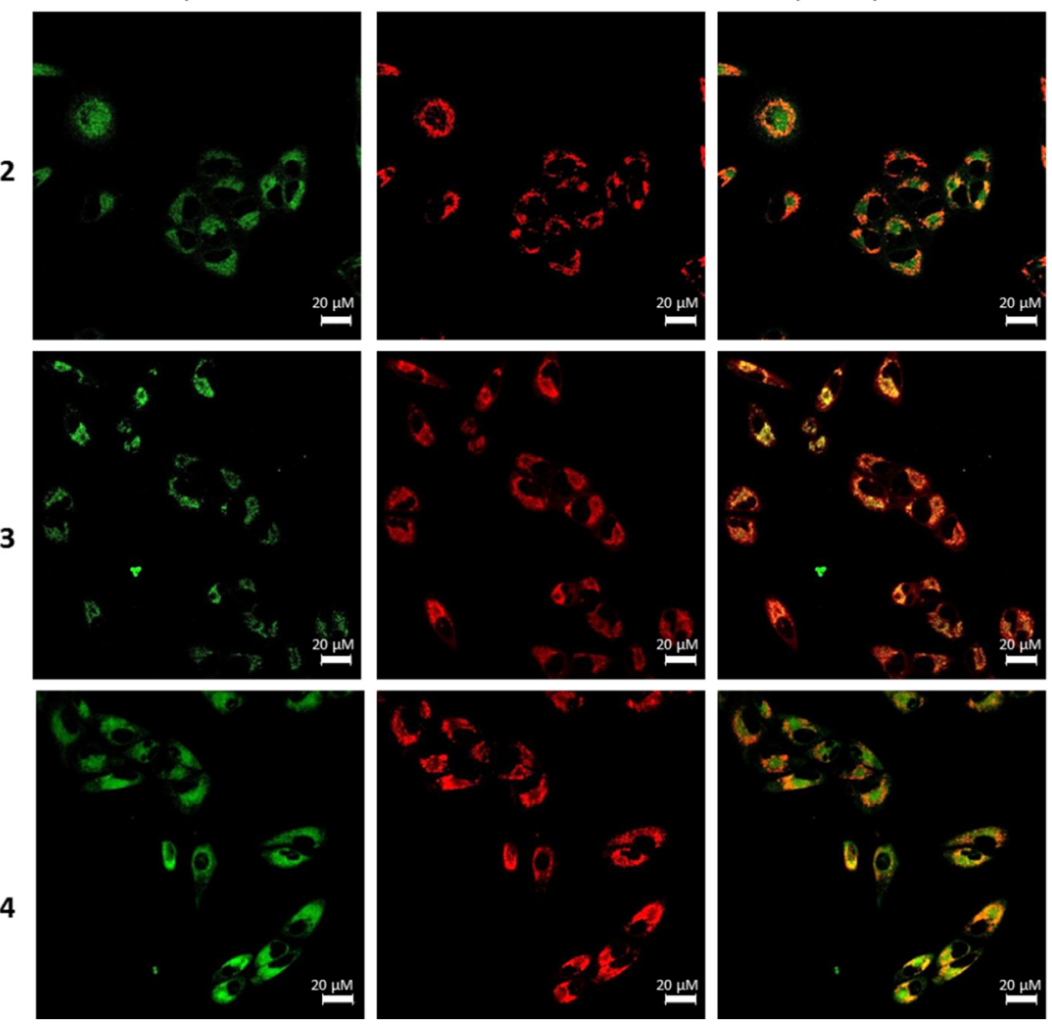

Figure 8. Fluorescence confocal microscopy images in A549 cells incubated with complexes 2, 3, 4 (green, irradiated at $458 \mathrm{~nm}$ ) and stained with MTR (red, irradiation at $598 \mathrm{~nm}$ ).

A closer look to Figure 9 also suggests that, apart from a partial mitochondrial localization, complexes $\mathbf{2}$ and $\mathbf{4}$ have an additional biodistribution close to the nuclear region. This distinct pattern was not seen for complex 3 and it might be related to the different coupled chromophore, i.e., acridine for $\mathbf{2}$ and $\mathbf{4}$ and anthracene in the case of complex 3 . The nitrogen present in the acridine is in fact, the only structural difference between the complexes. Recently Zhao, Zhang and coworkers also described a mitochondrial selective Ir(III) complex containing an anthracene moiety [39] and, once again, suggesting the role that the chromophore might be exerting on the biodistribution behavior. On the contrary, the distribution of the complexes in this case might point to a localization in the Golgi apparatus, since the cisternae of the complex are usually found together and near the nuclear region [40]. In fact, some $\operatorname{Ir}(\mathrm{III})$ compounds have been described that accumulate in the Golgi apparatus [41,42]. Notwithstanding, further studies are required to fully clarify the distribution of complexes 2 and 4 within cells.
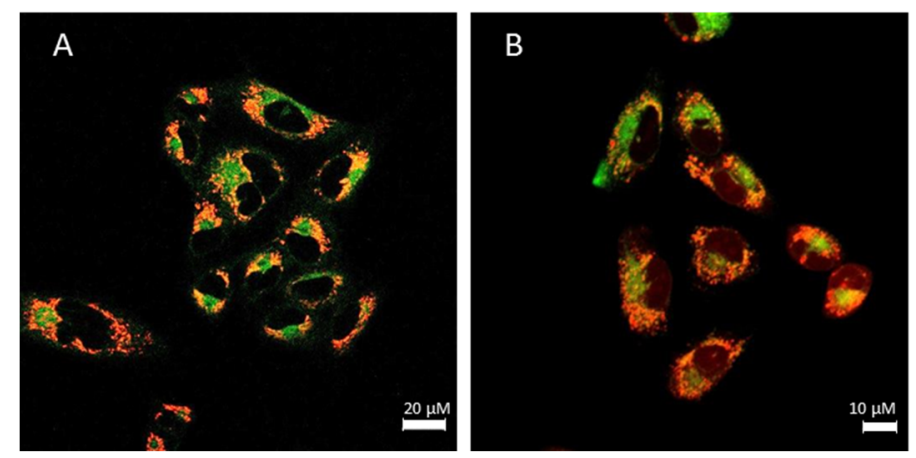

Figure 9. Superimposition images in A549 cells of complexes 2 (A) and 4 (B) incubated $2 \mathrm{~h}$ and stained with MitoTracker Red (MTR). 


\subsection{ROS Generation Potential}

After seeing that the PI of 4 is 111.4 times and knowing that such increment could be driven by the generation of ROS species as a consequence of phototherapeutic effect that the probe might exert upon irradiation, an assessment on the generation of ROS was undertaken by flow cytometry using dihydroethidium (DHE) as a fluorescent probe. The DHE probe is oxidized in presence of the superoxide ion to 2-HE (2-hydroxyethidium). The assay was performed once again in dark and upon irradiation conditions and the result is depicted in Figure 10. Thus, complex 4 showed a concentration-dependent ROS generation in both assay conditions and ROS production was greater when the complex at high doses was irradiated at $470 \mathrm{~nm}$ for $10 \mathrm{~min}$. Interestingly, each condition yielded different ROS production profiles. When the compound was not irradiated, a single peak shifted to the right is observed, as a sign of an increase in ROS generation at a general level; in contrast, when irradiating at high doses, two peaks are observed, one shifted to the right and the other remaining at the control level. This implies that a fraction of the cells has overactivated their ROS production mechanism whereas the rest maintain production levels similar to those of untreated cells. These high levels of ROS might be a consequence of the activation of the iridium complex that enables to reach the iridium complexes a triplet excited state. At this point an electron transfer process (PDT type I) and/or energy transfer process (PDT type II) takes places generating the highly cytotoxic ROS [43]. In conclusion, A549 cells enhanced ROS production after exposition to non-irradiated or especially to irradiated complex 4.
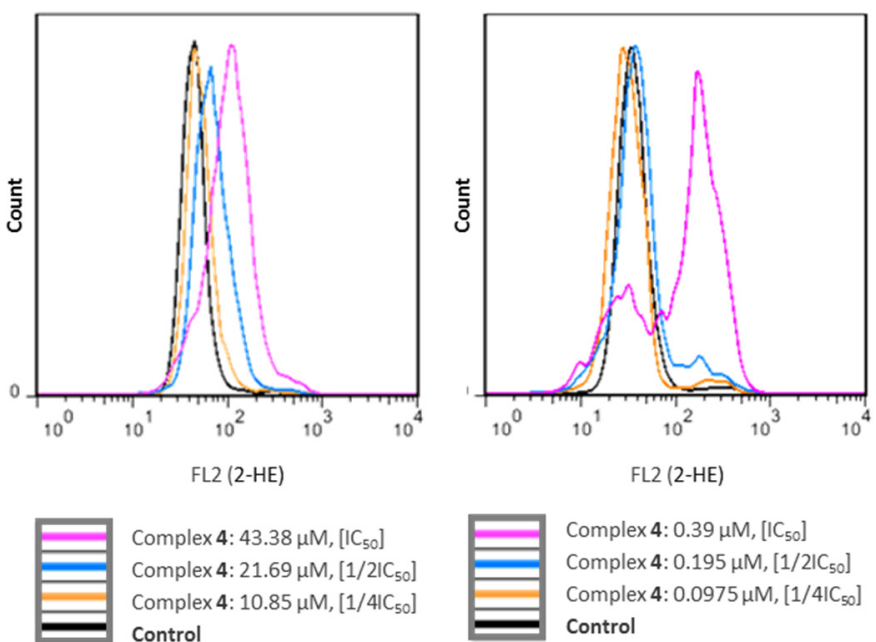

Figure 10. Generation of ROS induced by complex 4 at increasing concentrations in dark (left graph) and upon irradiation at $470 \mathrm{~nm}$ (right graph).

\section{Conclusions}

Four new luminescent and photosensitive iridium(III) complexes of the type $\left[\operatorname{Ir}\left(\mathrm{C}^{\wedge} \mathrm{N}\right)_{2}\left(\mathrm{~N}^{\wedge} \mathrm{N}-\mathrm{R}\right)\right]^{+}$, where $\mathrm{N}^{\wedge} \mathrm{C}$ is either phenylpyridine (ppy) or benzoquinoline (bzq), $\mathrm{N}^{\wedge} \mathrm{N}$ is 2,2'-dipyridylamine (dpa) and $\mathrm{R}$ either acridine or anthracene, have been synthesized and their emissive and bioactivity properties against A549 cell line have been studied. The optical analysis showed an excitation dependent emissive pattern for all the complexes which was more evident in the case of complex 4 . Specifically, complex 4 clearly showed that the main emissive band was due to the organic chromophore (LC transition) when the irradiation was performed between 374 and $400 \mathrm{~nm}$ with a structured band between 407 and $450 \mathrm{~nm}$, whereas irradiating at different wavelength ranges, the main emission was centered c.a. $525 \mathrm{~nm}$, and it was due to the iridium fragment $\left({ }^{3} \mathrm{MLCT}\right.$ and ${ }^{3}$ LLCT transition). The difference on the emissive origin (acridine vs. $\operatorname{Ir}(\mathrm{III})$ fragment) was reflected in the photocytotoxic properties observed upon incubation with A549 cells All the complexes displayed moderate antiproliferative activity, being complex 4 the least 
potent. However, under irradiation conditions their bioactivity increases especially when the irradiation affects the $\operatorname{Ir}(\mathrm{III})$ core. Thus, complex 4 has an $\mathrm{IC}_{50}$ value of $43.38 \pm 0.14 \mu \mathrm{M}$ in dark, $\mathrm{IC}_{50}>5 \mu \mathrm{M}$ upon irradiation for $10 \mathrm{~min}$ at $405 \mathrm{~nm}$ and $\mathrm{IC}_{50}$ of $0.39 \pm 0.09 \mu \mathrm{M}$ upon irradiation for $10 \mathrm{~min}$ at $470 \mathrm{~nm}$. These results emphasize the importance of the intrinsic photophysical properties of $\operatorname{Ir}(\mathrm{III})$ core over that of organic chromophores for delivering upgraded PSs. Microscopy analysis revealed cytoplasmic vacuolization and typical apoptotic and necrotic features which were confirmed by cytotoxicity assays, suggesting that complex 4 prompts paraptotic and apoptotic cell death. In fact, we have previously described several heterometallic $\operatorname{Ir}(\mathrm{III})-\mathrm{Au}(\mathrm{I})$ compounds that appear to activate the paraptotic pathway first and the apoptotic pathway ultimately [14]. Confocal fluorescence microscopy studies propose that complex 3 entirely localized in mitochondria, and compounds $\mathbf{2}$ and $\mathbf{4}$, although also partly localized in these organelles, present other subcellular distribution. As both complexes ( 2 and 4$)$ contain the same chromophore (acridine) it can be suggested that the chromophore's role within subcellular localization is not innocent. However, further biodistribution assays need to be performed prior to stablish any structure/localization relationship. Moreover, no cell cycle alterations were detected but a greater ROS generation was observed under dark and irradiation conditions. These complexes are the proof of concept that it is possible to deliver dual emissive Ir(III) probes as effective PSs for PDT and cell imaging agents. Despite the promising results, further structural modifications are needed to obtain future agents that absorb in the red or near infrared range, the phototherapeutic window.

Supplementary Materials: The following are available online at https:/ /www.mdpi.com/article/10 .3390/pharmaceutics13091382/s1, Figure S1: ${ }^{1} \mathrm{H}-\mathrm{NMR}$ spectrum of compound L1, Figure S2: APTNMR spectrum of compound L1, Figure S3: ${ }^{1} \mathrm{H}-\mathrm{NMR}$ spectrum of compound L2, Figure S4: APTNMR spectrum of compound L2; Figure S5: ${ }^{1} \mathrm{H}-\mathrm{NMR}$ spectrum of complex 1, Figure S6: APT-NMR spectrum of complex 1, Figure S7: ${ }^{1} \mathrm{H}-\mathrm{NMR}$ spectrum of complex 2, Figure S8: APT-NMR spectrum of complex 2, Figure S9: ${ }^{1} \mathrm{H}-\mathrm{NMR}$ spectrum of complex 3, Figure S10: APT-NMR spectrum of complex 3, Figure S11: ${ }^{1} \mathrm{H}-\mathrm{NMR}$ spectrum of complex 4, Figure S12: APT-NMR spectrum of complex 4, Figure S13: Emission-spectra of L1 measured in DMSO solution, Figure S14: Emission-spectra of L2 measured in DMSO solution, Figure S15: Emission-spectra of $\mathbf{1}$ measured in DMSO solution, Figure S16: Emission-spectra of 2 measured in DMSO solution, Figure S17: Emission-spectra of 3 measured in DMSO solution, Figure S18: Emission-spectra of 4 measured in DMSO solution, Figure S19: Absorption spectra in DMSO solution, Figure S20: Fluorescence confocal microscopy images of A549 cells incubated with $2(2 \mathrm{~h})$ and stained with MTR, Figure S21: Fluorescence confocal microscopy images of A549 cells incubated with $3(2 \mathrm{~h})$ and stained with MTR, Figure S22: Fluorescence confocal microscopy images of A549 cells incubated with $4(2 \mathrm{~h})$ and stained with MTR.

Author Contributions: Conceptualization, V.F.-M. and M.C.G.; Synthesis of the probes, M.R.; Evaluation of the photophysical properties, M.R. and V.F.-M.; Evaluation of the Bioactive properties, M.R., A.B. and I.M.; data curation, V.F.-M., M.R. and A.B.; writing-original draft preparation, V.F.-M., A.B. and M.R.; writing - review and editing, V.F.-M.; supervision, V.F.-M.; project administration, V.F.-M. and M.C.G.; funding acquisition, V.F.-M. and M.C.G. All authors have read and agreed to the published version of the manuscript.

Funding: This research was funded by the Agencia Estatal de Investigación (projects PID2019104379RB-C21, RTI2018-097836-J-I00, RYC2018-025872-I and RED2018-102471-T), and Gobierno de Aragón-Fondo Social Europeo (E07_20R).

Institutional Review Board Statement: Not applicable.

Informed Consent Statement: Not applicable.

Data Availability Statement: Data is contained within the article or supplementary material.

Acknowledgments: Authors thank the Agencia Estatal de Investigación (projects PID2019-104379RBC21, RTI2018-097836-J-I00, RYC2018-025872-I and RED2018-102471-T), and Gobierno de AragónFondo Social Europeo (E07_20R) for financial support. M.R.D thanks the Gobierno de Aragón for a 
predoctoral fellowship. In addition, authors would like to acknowledge the use of Servicio General de Apoyo a la Investigación-SAI, Universidad de Zaragoza.

Conflicts of Interest: The authors declare no conflict of interest.

\section{References}

1. Abels, C. Targeting of the vascular system of solid tumours by photodynamic therapy (PDT). Photochem. Photobiol. Sci. 2004, 3, 765-771. [CrossRef]

2. Castano, A.P.; Mroz, P.; Hamblin, M.R. Photodynamic therapy and anti-tumour immunity. Nat. Rev. Cancer 2006, 6, 535-545. [CrossRef] [PubMed]

3. Mroz, P.; Szokalska, A.; Wu, M.X.; Hamblin, M.R. Photodynamic therapy of tumors can lead to development of systemic antigen-specific immune response. PLoS ONE 2010, 5, e15194. [CrossRef] [PubMed]

4. Dabrowski, J.M. Reactive Oxygen Species in Photodynamic Therapy: Mechanisms of Their Generation and Potentiation. Adv. Inorg. Chem. 2017, 70, 343-394. [CrossRef]

5. McKenzie, L.K.; Bryant, H.E.; Weinstein, J.A. Transition metal complexes as photosensitisers in one- and two-photon photodynamic therapy. Coord. Chem. Rev. 2019, 379, 2-29. [CrossRef]

6. Josefsen, L.B.; Boyle, R.W. Photodynamic therapy and the development of metal-based photosensitisers. Met.-Based Drugs 2008, 2008, 276109. [CrossRef] [PubMed]

7. Stacey, O.J.; Pope, S.J.A. New avenues in the design and potential application of metal complexes for photodynamic therapy. RSC Adv. 2013, 3, 25550-25564. [CrossRef]

8. Monro, S.; Colón, K.L.; Yin, H.; Roque, J.; Konda, P.; Gujar, S.; Thummel, R.P.; Lilge, L.; Cameron, C.G.; McFarland, S.A. Transition metal complexes and photodynamic therapy from a tumor-centered approach: Challenges, opportunities, and highlights from the development of TLD1433. Chem. Rev. 2019, 119, 797-828. [CrossRef]

9. Caporale, C.; Massi, M. Cyclometallated iridium(III) complexes for life science. Coord. Chem. Rev. 2018, 363, 71-91. [CrossRef]

10. Zamora, A.; Vigueras, G.; Rodríguez, V.; Santana, M.D.; Ruiz, J. Cyclometallated iridium(III) luminescent complexes in therapy and phototherapy. Coord. Chem. Rev. 2018, 360, 34-76. [CrossRef]

11. Ouyang, M.; Zeng, L.; Huang, H.; Jin, C.; Liu, J.; Chen, Y.; Jia, L.; Chao, H. Fluorinated cyclometallated iridium(III) complexes as mitochondria-targeted theranostic anticancer agents. Dalton Trans. 2017, 46, 6734-6744. [CrossRef] [PubMed]

12. Liu, S.; Liang, H.; Zhang, K.Y.; Zhao, Q.; Zhou, X.; Xua, W.; Huang, W. A multifunctional phosphorescent iridium(III) complex for specific nucleus staining and hypoxia monitoring. Chem. Commun. 2015, 51, 7943-7946. [CrossRef]

13. Luengo, A.; Marzo, I.; Reback, M.; Daubit, I.M.; Fernández-Moreira, V.; Metzler-Nolte, N.; Gimeno, M.C. Luminescent bimetallic IrIII/ AuI peptide bioconjugates as potential theranostic agents. Chem. Eur. J. 2020, 26, 12158-12167. [CrossRef] [PubMed]

14. Redrado, M.; Benedi, A.; Marzo, I.; García-Otín, A.L.; Fernández-Moreira, V.; Gimeno, M.C. Multifunctional heterometallic IrIII-AuI probes as promising anticancer and antiangiogenic agents. Chem. Eur. J. 2021, 27, 9885-9897. [CrossRef]

15. Mahalingam, S.M.; Ordaz, J.D.; Low, P.S. Targeting of a photosensitizer to the mitochondrion enhances the potency of photodynamic therapy. ACS Omega 2018, 3, 6066-6074. [CrossRef]

16. Jeena, M.T.; Kim, S.; Jin, S.; Ryu, J.-H. Recent progress in mitochondria-targeted drug and drug-free agents for cancer therapy. Cancers 2020, 12, 4. [CrossRef]

17. Rubio, N.; Fleury, S.P.; Redmond, R.W. Spatial and temporal dynamics of in vitro photodynamic cell killing: Extracellular hydrogen peroxide mediates neighbouring cell death. Photochem. Photobiol. Sci. 2009, 8, 457-464. [CrossRef]

18. Wilson, B.C.; Olivo, M.; Singh, G. Subcellular localization of photofrin and aminolevulinic acid and photodynamic cross-resistance in vitro in radiation-induced fibrosarcoma cells sensitive or resistant to photofrin-mediated photodynamic therapy. Photochem. Photobiol. 1997, 65, 166-176. [CrossRef]

19. Belzacq, A.; Jacotot, E.; Vieira, H.L.A.; Mistro, D.; Granville, D.J.; Xie, Z.; Reed, J.C.; Kroemer, G.; Brenner, C. Apoptosis induction by the photosensitizer verteporfin: Identification of mitochondrial adenine nucleotide translocator as a critical target. Cancer Res. 2001, 61, 1260-1264.

20. Arnaut, L.G.; Pereira, M.M.; Dąbrowski, J.M.; Silva, E.F.F.; Schaberle, F.A.; Abreu, A.R.; Rocha, L.B.; Barsan, M.M.; Urbańska, K.; Stochel, G.; et al. Photodynamic Therapy Efficacy Enhanced by Dynamics: The Role of Charge Transfer and Photostability in the Selection of Photosensitizers. Chem. Eur. J. 2014, 20, 5346-5357. [CrossRef] [PubMed]

21. Dąbrowski, J.M.; Arnaut, L.G.; Pereira, M.M.; Urbańska, K.; Simões, S.; Stochel, G.; Cortes, L. Combined effects of singlet oxygen and hydroxyl radical in photodynamic therapy with photostable bacteriochlorins: Evidence from intracellular fluorescence and increased photodynamic efficacy in vitro. Free Radic. Biol. Med. 2012, 52, 1188-1200. [CrossRef]

22. Song, X.D.; Chen, B.B.; He, S.F.; Pan, N.L.; Liao, J.X.; Chen, J.X.; Wang, G.H.; Sun, J. Guanidine-modified cyclometallated iridium(III) complexes for mitochondria-targeted imaging and photodynamic therapy. Eur. J. Med. Chem. 2019, $179,26-37$. [CrossRef] [PubMed]

23. Pracharova, J.; Vigueras, G.; Novohradsky, V.; Cutillas, N.; Janiak, C.; Kostrhunova, H.; Kasparkova, J.; Ruiz, J.; Brabec, V. Exploring the effect of polypyridyl ligands on the anticancer activity of phosphorescent iridium(III) complexes: From proteosynthesis inhibitors to photodynamic therapy agents. Chem. Eur. J. 2018, 24, 4607-4619. [CrossRef] [PubMed] 
24. Xie, Y.; Ding, Y.; Li, X.; Wang, C.; Hill, J.P.; Ariga, K.; Zhang, W.; Zhua, W. Selective, sensitive and reversible "turn-on" fluorescent cyanide probes based on 2,20-dipyridylaminoanthracene-Cu2+ ensembles. Chem. Commun. 2012, 48, 11513-11515. [CrossRef] [PubMed]

25. Fulmer, G.R.; Miller, A.J.M.; Sherden, N.H.; Gottlieb, H.E.; Nudelman, A.; Stoltz, B.M.; Bercaw, J.E.; Goldberg, K.I. NMR chemical shifts of trace impurities: Common laboratory solvents, organics, and gases in deuterated solvents relevant to the organometallic chemist. Organometallics 2010, 29, 2176-2179. [CrossRef]

26. García-Moreno, E.; Cerrada, E.; Bolsa, M.J.; Luquin, A.; Laguna, M. Water-soluble phosphanes derived from 1,3,5-triaza-7phosphaadamantane and their reactivity towards gold(I) complexes. Eur. J. Inorg. Chem. 2013, 2013, 2020-2030. [CrossRef]

27. Sprouse, S.; King, K.A.; Spellane, P.J.; Watts, R.J. Photophysical effects of metal-carbon. sigma. bonds in ortho-metalated complexes of iridium(III) and rhodium(III). J. Am. Chem. Soc. 1984, 106, 6647-6653. [CrossRef]

28. Visbal, R.; Laguna, A.; Gimeno, M.C. N-Heterocyclic Carbene Coinage Metal Complexes as Intense Blue-Green Emitters. Organometallics 2012, 31, 7146-7157. [CrossRef]

29. Visbal, R.; Gimeno, M.C. N-heterocyclic carbene metal complexes: Photoluminescence and applications. Chem. Soc. Rev. 2014, 43, 3551-3574. [CrossRef]

30. Vaquero, M.; Ruiz-Riaguas, A.; Martínez-Alonso, M.; Jalón, F.A.; Manzano, B.R.; Rodríguez, A.M.; García-Herbosa, G.; Carbayo, A.; García, B.; Espino, G. Selective photooxidation of sulfides catalyzed by bis-cyclometallated IrIII photosensitizers bearing 2,2'-dipyridylamine-based ligands. Chem. Eur. J. 2018, 24, 10662-10671. [CrossRef]

31. Costa, R.D.; Ortí, E.; Bolink, H.J.; Monti, F.; Accorsi, G.; Armaroli, N. Luminescent ionic transition-metal complexes for lightemitting electrochemical cells. Angew. Chem. Int. Ed. 2012, 51, 8178-8211. [CrossRef] [PubMed]

32. Bhat, S.S.; Revankar, V.K.; Pinjari, R.V.; Naveen, S.; Lokanath, N.K.; Kumbar, V.; Bhate, K.; Kokarea, D.G. Phosphorescent cyclometallated iridium(III) complexes: Synthesis, photophysics, DNA interaction, cellular internalization, and cytotoxic activity. New J. Chem. 2018, 42, 16846-16854. [CrossRef]

33. Ladouceur, S.; Fortin, D.; Zysman-Colman, E. Enhanced luminescent iridium(III) complexes bearing aryltriazole cyclometallated ligands. Inorg. Chem. 2011, 50, 11514-11526. [CrossRef]

34. Van Engeland, M.; Nieland, L.J.; Ramaekers, F.C.; Schutte, B.; Reutelingsperger, C.P. Annexin V-affinity assay: A review on an apoptosis detection system based on phosphatidylerine exposure. Cytom. J. Int. Soc. Anal. Cytol. 1998, 31, 1-9. [CrossRef]

35. Sperandio, S.; Poksay, K.S.; Schilling, B.; Danielle, C.; Gibson, B.W.; Bredsen, D.E. Identification of new modulators and protein alterations in non-apoptotic programmed cell death. J. Cell Biochem. 2010, 111, 1401-1412. [CrossRef] [PubMed]

36. Kops, G.J.P.L.; Weaver, B.A.A.; Cleveland, D.W. On the road to cancer: Aneuploidy and mitotic Checkpoint. Nat. Rev. Cancer 2005, 5, 773-785. [CrossRef]

37. Amezqueta, S.; Subirats, X.; Fuguet, E.; Roses, M.; Rafols, C. Chapter 6-Octanol-Water Partition Constant. In Handbooks in Separation Science: Liquid-Phase Extraction; Elsevier: Amsterdam, The Netherlands, 2020.

38. Lipinski, C.A.; Lombardo, F.; Dominy, B.W.; Feeney, P.J. Experimental and computational approaches to estimate solubility and permeability in drug discovery and development settings. Adv. Drug Deliv. Rev. 2001, 46, 3-26. [CrossRef]

39. Liu, X.; Dai, P.; Gu, T.; Wu, Q.; Wei, H.; Liu, S.; Zhang, K.Y.; Zhao, Q. Cyclometallated iridium(III) complexes containing an anthracene unit for sensing and imaging singlet oxygen in cellular mitochondria. J. Inorg. Biochem. 2020, 209, 111106-111116. [CrossRef] [PubMed]

40. Lennarz, W.; Lane, M.; Modrich, P.; Dixon, J.; Carafoli, E.; Exton, J.; Cleveland, D. Golgi Complex. In Encyclopedia of Biological Chemistry; Elsevier: Amsterdam, The Netherlands, 2004. [CrossRef]

41. Ho, C.-L.; Wong, K.-L.; Kong, H.-K.; Ho, Y.-M.; Chan, C.T.-L.; Kwok, W.-M.; Leung, K.S.-Y.; Tam, H.-L.; Lam, M.H.-W.; Ren, X.-F.; et al. A strong two-photon induced phosphorescent Golgi-specific in vitro marker based on a heteroleptic iridium complex. Chem. Commun. 2012, 48, 2525-2527. [CrossRef] [PubMed]

42. Lo, K.K.-W.; Zhang, K.Y. Iridium (III) complexes as therapeutic and bioimaging reagents for cellular applications. RSC Adv. 2012, 2, 12069-12083. [CrossRef]

43. Huang, H.; Banerjee, S.; Sadler, P.J. Recent advances in the design of targeted iridium(III) photosensitizers for photodynamic therapy. ChemBioChem 2018, 19, 1574-1589. [CrossRef] [PubMed] 